OPEN ACCESS

Edited by:

John Maher,

King's College London,

United Kingdom

Reviewed by:

Michael Jain

Moffitt Cancer Center, United States

Julio C. Chavez,

Moffitt Cancer Center, United States

${ }^{*}$ Correspondence:

Benedetto Bruno

benedetto.bruno@unito.it

tThese authors have contributed equally to this work

Specialty section:

This article was submitted to

Cancer Immunity and Immunotherapy,

a section of the journal

Frontiers in Immunology

Received: 20 February 2020

Accepted: 17 April 2020

Published: 12 May 2020

Citation:

Cerrano $M$, Ruella $M$, Perales M-A,

Vitale C, Faraci DG, Giaccone L,

Coscia M, Maloy M,

Sanchez-Escamilla M, Elsabah $H$,

Fadul A, Maffini E, Pittari $G$ and

Bruno B (2020) The Advent of CAR

T-Cell Therapy for Lymphoproliferative Neoplasms: Integrating Research Into

Clinical Practice.

Front. Immunol. 11:888

doi: 10.3389/fimmu.2020.00888

\title{
The Advent of CAR T-Cell Therapy for Lymphoproliferative Neoplasms: Integrating Research Into Clinical Practice
}

\begin{abstract}
Marco Cerrano ${ }^{1,2+}$, Marco Ruella ${ }^{3 \dagger}$, Miguel-Angel Perales ${ }^{4}$, Candida Vitale ${ }^{1,2}$, Danilo Giuseppe Faraci ${ }^{1,2}$, Luisa Giaccone ${ }^{1,2}$, Marta Coscia ${ }^{1,2}$, Molly Maloy ${ }^{4}$, Miriam Sanchez-Escamilla ${ }^{4,5}$, Hesham Elsabah ${ }^{6}$, Afraa Fadul ${ }^{6}$, Enrico Maffini ${ }^{7}$, Gianfranco Pittari ${ }^{6+}$ and Benedetto Bruno ${ }^{1,2 \times+}$
\end{abstract}

${ }^{1}$ Department of Oncology/Hematology, A.O.U. Città della Salute e della Scienza di Torino, Turin, Italy, ${ }^{2}$ Department of Molecular Biotechnology and Health Sciences, University of Torino, Turin, Italy, ${ }^{3}$ Department of Pathology and Laboratory Medicine, Abramson Cancer Center, University of Pennsylvania, Philadelphia, PA, United States, ${ }^{4}$ Adult Bone Marrow Transplantation Service, Department of Medicine, Memorial Sloan-Kettering Cancer Center and Weill Cornell Medical College, New York, NY, United States, ${ }^{5}$ Department of Hematological Malignancies and Stem Cell Transplantation, Research Institute of Marques de Valdecilla (IDIVAL), Santander, Spain, ${ }^{6}$ Department of Medical Oncology, Hematology/BMT Service, National Center for Cancer Care and Research, Hamad Medical Corporation, Doha, Qatar, ${ }^{7}$ Hematology and Stem Cell

Transplant Unit, Romagna Transplant Network, Ravenna, Italy

Research on CAR T cells has achieved enormous progress in recent years. After the impressive results obtained in relapsed and refractory B-cell acute lymphoblastic leukemia and aggressive B-cell lymphomas, two constructs, tisagenlecleucel and axicabtagene ciloleucel, were approved by FDA. The role of CAR T cells in the treatment of B-cell disorders, however, is rapidly evolving. Ongoing clinical trials aim at comparing CAR T cells with standard treatment options and at evaluating their efficacy earlier in the disease course. The use of CAR T cells is still limited by the risk of relevant toxicities, most commonly cytokine release syndrome and neurotoxicity, whose management has nonetheless significantly improved. Some patients do not respond or relapse after treatment, either because of poor CAR T-cell expansion, lack of anti-tumor effects or after the loss of the target antigen on tumor cells. Investigators are trying to overcome these hurdles in many ways: by testing constructs which target different and/or multiple antigens or by improving CAR T-cell structure with additional functions and synergistic molecules. Alternative cell sources including allogeneic products (off-the-shelf CAR T cells), NK cells, and T cells obtained from induced pluripotent stem cells are also considered. Several trials are exploring the curative potential of CAR T cells in other malignancies, and recent data on multiple myeloma and chronic lymphocytic leukemia are encouraging. Given the likely expansion of CAR T-cell indications and their wider availability over time, more and more highly specialized clinical centers, with dedicated clinical units, will be required. Overall, the costs of these cell therapies will also play a role in the sustainability of many health care systems. This review will focus on the major clinical trials of CAR T cells in B-cell malignancies, including those leading to the first 
FDA approvals, and on the new settings in which these constructs are being tested. Besides, the most promising approaches to improve CAR T-cell efficacy and early data on alternative cell sources will be reviewed. Finally, we will discuss the challenges and the opportunities that are emerging with the advent of CAR T cells into clinical routine.

Keywords: CAR T cells, adoptive immunotherapy, cellular therapy, lymphoma, leukemia

\section{INTRODUCTION}

Chimeric antigen receptors (CARs) are artificial proteins whose basic structure is composed of an antigen recognition ectodomain and an activation endodomain, linked by a spacer and a transmembrane domain (1). The ectodomain is a fusion protein encompassing single $\mathrm{VH}$ and VL regions of an immunoglobulin, joined by a linker peptide, i.e., a single-chain variable fragment $(\mathrm{scFv})$, capable of non-MHC restricted surface antigen recognition (2-4). The endodomain is responsible for the intracellular signal transduction which follows T-cell activation and for the functional cytotoxic properties of the transduced cell, and its basic structure includes a CD3-derived component critical for transduction of activating signals triggered by a native T-cell receptor (TCR), predominantly a CD3ל moiety containing immunoreceptor tyrosine-based activation motifs (ITAMs) (5).

CAR-based cellular immunotherapy was initially tested in patients with hematologic malignancies, and CD19 was selected as a preferential target antigen, based on its selective expression on B cells, therefore limiting on-target off-tumor side effects to Bcell aplasia, which may also protect against the risk of developing CAR-directed antibodies. Initial studies on autologous $\mathrm{T}$ cells engineered with anti-CD19 first-generation CARs demonstrated short effector persistence in vivo, despite multiple infusions (6). These suboptimal clinical outcomes were later circumvented by using autologous $\mathrm{T}$ cells engineered with upgraded CAR constructs, incorporating a co-stimulatory endodomain, typically $\mathrm{CD} 28$ or $4-1 \mathrm{BB}$. These second-generation CAR constructs were intended to provide $\mathrm{T}$ cells with a supplementary activation signal upon ligand engagement, thus mimicking the physiologic second signal generated by $\mathrm{CD} 28$ independent binding to CD80/86 ligands following TCR antigen recognition. Alternative signaling from $4-1 \mathrm{BB}$ or $\mathrm{CD} 28$ in the context of secondgeneration CARs elicits non-overlapping pathways, resulting in $\mathrm{T}$ cells with remarkably distinct qualities. Specifically, CD28 generates a more rapid and intense co-stimulatory signal, compared to $4-1 \mathrm{BB}$, in spite of a less durable cytotoxic activity and a shorter in vivo persistence of CAR $\mathrm{T}$ cells $(7,8)$.

Currently, two different second-generation anti-CD19 CAR T-cell products have been approved by US Food and Drug Administration (FDA) and by European Medicine Agency (EMA) for clinical use, but certainly further advancements are needed, in order to improve efficacy, broaden the spectrum of target diseases, and mitigate side effects. In addition, efforts are required to translate pre-clinical and early stage clinical research innovations into clinical practice.

\section{MAJOR CLINICAL STUDIES INVOLVING ANTI-CD19 CAR T CELLS \\ Early Studies of CAR T Cells in Lymphoid Neoplasms}

After the seminal studies of this unique form of adoptive T-cell therapy led by Eshhar and Goverman $(9,10)$, the breakthrough of CAR-based strategy emerged with the treatment of B-cell malignancies in the first decade of 2000s. Following the initial preclinical observations from Seattle Children's Hospital on the activity of first and second-generation constructs $(11,12)$, in 2010 Rosenberg and colleagues from National Cancer Institute (NCI) reported the first clinical response to an anti-CD19 CAR $\mathrm{T}$-cell product in a patient with advanced follicular lymphoma (FL) (13). Shortly after, several early-phase studies confirmed the impressive anti-tumor effect of second-generation CAR T cells in heavily pretreated patients with B-cell malignancies, but also outlined the significant toxicities associated with this treatment, the most frequent being cytokine release syndrome (CRS) and neurotoxicity (NTX) (see below) (14-16).

The Memorial Sloan Kettering Cancer Center (MSKCC) group reported significant activity of their CD28 construct in B-cell acute lymphoblastic leukemia (B-ALL) in $5 \mathrm{R} / \mathrm{R}$ patients, all achieving a measurable residual disease (MRD) negative complete remission (CR) (17), although CRS was significant. Indeed, in keeping with observations in animal studies (12), $\mathrm{T}$ cells engineered with a CD19-specific second-generation CD28/CD3 $\zeta$ dual-signaling CAR (CD19-28z) displayed superior in vivo persistence than first-generation ones, and resulted in favorable clinical responses in ALL and in patients with advanced B-cell Non-Hodgkin lymphomas (B-NHL) $(18,19)$. Another CD28 construct, KTE-C19 - now developed as axi-cel - designed at the NCI, was successfully employed in patients with refractory diffuse large B cell lymphoma (DLBCL) and indolent B-cell malignancies, showing a response in $12 / 15$ cases, including 8 CR (18). Signs of CRS and/or NTX were observed in the majority of patients.

Similarly, T cells transduced with a anti CD19 CAR containing the 4-1BB and $\mathrm{CD} 3 \zeta$ signaling domains (CD19-BBz) exhibited prolonged in vivo persistence and expansion, correlating with sustained clinical benefit in individuals with R/R B-ALL (16) and chronic lymphocytic leukemia (CLL) (14). Investigators of the University of Pennsylvania (UPenn), after showing the efficacy of their CD19-BBz construct CTL019 - now developed as tisacel - in 2 children with R/R B-ALL achieving CR (20), reported on a single-center phase I/IIa study on $30 \mathrm{R} / \mathrm{R}$ B-ALL patients. Morphologic CR was obtained in $90 \%$ of patients, and 6-month event-free survival (EFS) was 67\%. All patients developed CRS, 


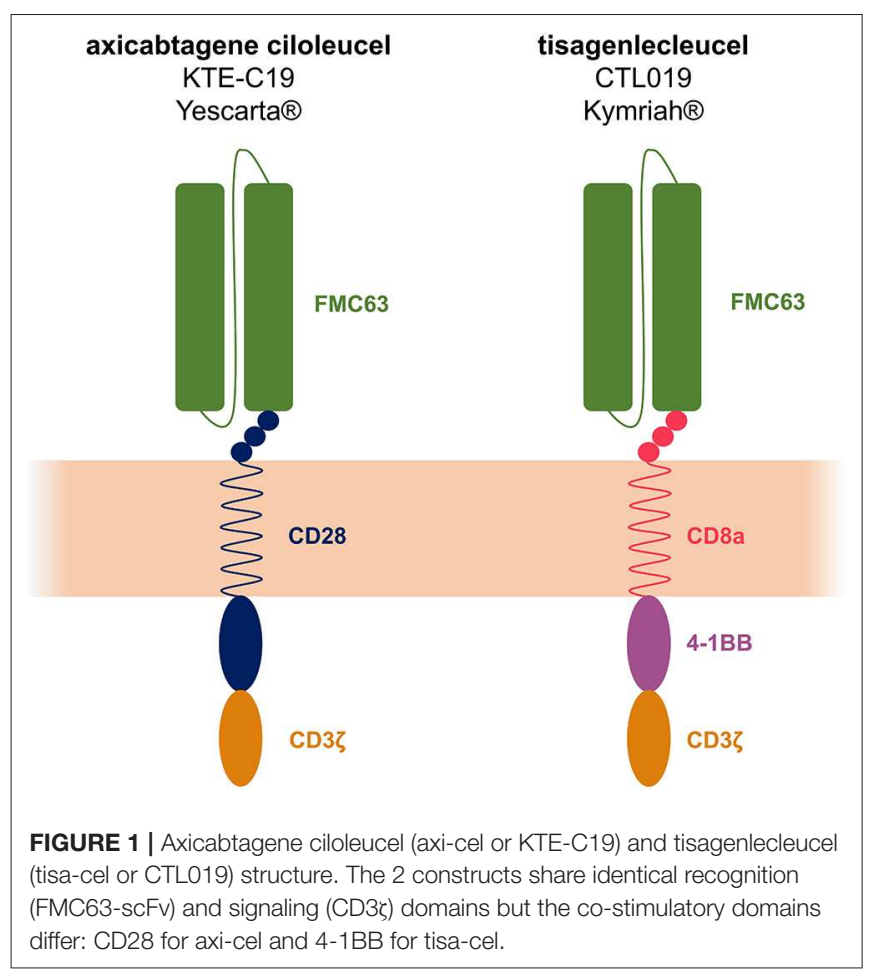

which was severe in $27 \%$ of the cases (16). In CLL, the same construct was tested in a single center pilot study including 14 heavily pretreated patients. Overall response rate (ORR) was 57\%, and CR rate was 29\%. Median duration of response was 40 months for CR patients, and CRS and NTX occurred in nine and five cases, respectively (14).

\section{Studies Leading to FDA-Approval of CAR T Cells}

The FDA granted the autologous CAR T-cell therapy tisagenlecleucel (CTL019 or tisa-cel, KYMRIAH ${ }^{\circledR}$, jointly developed by the UPenn and Novartis) breakthrough therapy designation for pediatric and young adult R/R B-ALL in July 2014. In August 2017 the FDA announced the approval of tisagenlecleucel for the treatment of R/R B-ALL for patients up to 25 years of age. An additional autologous anti-CD19 CAR T-cell therapy was FDA-approved in October 2017, i.e., axicabtagene ciloleucel (axi-cel, YESCARTA ${ }^{\circledR}$, Kite Pharma Inc.) for adult patients with $\mathrm{R} / \mathrm{R} \mathrm{DLBCL}$, primary mediastinal large $\mathrm{B}$-cell lymphoma (PMBCL), high grade B-cell lymphoma and transformed FL. Soon after, tisagenlecleucel was also FDAapproved for adult with $\mathrm{R} / \mathrm{R}$ DLBCL (of note, tisa-cel is not labeled for PMBCL). In 2018, the European Medicines Agency (EMA) approved the two constructs for similar indications as well. Tisa-cel and axi-cel CAR constructs share identical

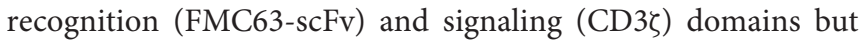
possess distinct co-stimulatory domains (i.e., 4-1BB and CD28 for tisa-cel and axi-cel, respectively, Figure 1).

ELIANA (CCTL019-B2202) was the first global CAR Tcell therapy registration trial that led to the FDA-approval of tisagenlecleucel for pediatric and young adults with R/R B-ALL (21). It was a multicenter single-arm phase II study enrolling a total of 92 patients. At enrollment, patients had received a median of three prior lines of therapy and $61 \%$ had failed a previous allogeneic hematopoietic stem cell transplantation (allo-HSCT). In the update analysis on 75 infused patients with a median follow-up of 13.1 months, best ORR was $81 \%$, with $60 \% \mathrm{CR}$, all of whom MRD negative ( $<0.01 \%$ by flow cytometry). Tisacel was detected in blood up to 20 months after the infusion. Twelve months EFS and overall survival (OS) were 50 and $76 \%$, respectively. Globally, $73 \%$ of the infused patients developed grade $3 / 4$ adverse events (AEs) suspected to be related to tisagenlecleucel, and $47 \%$ of them were admitted to the intensive care unit (ICU) for CRS management. Neurological events were observed in $40 \%$ of the cases within 8 weeks after the infusion, $13 \%$ being of grade 3 but none of grade 4 . Globally, $24 \%$ of patients were infused in the outpatient setting.

ZUMA-1 was the first multicenter phase I/II clinical trial testing axicabtagene ciloleucel in aggressive B-NHL (22, 23), leading to the approval of the product. The phase II portion of the trial enrolled 119 patients, of whom 108 were infused and 101 evaluated for clinical response. Enrolled patients suffered from R/R DLBCL (76\%), PMBCL (16\%), or transformed FL $(8 \%)$, and the majority of the cases had received at least three lines of chemotherapy before CAR T-cell infusion (69\%); $26 \%$ had primary refractory disease. After lymphodepleting chemotherapy with low-dose cyclophosphamide and fludarabine, patients received CAR T cells at target dose of $2 \times 10^{6}$ cells $/ \mathrm{kg}$. In this trial systemic bridging chemotherapy was not allowed after leukapheresis and the median time from leukapheresis to delivery of axi-cel to the treatment centers was 17 days. An updated analysis of the trial by Locke et al. showed a best ORR and CR rate of $83 \%$ and of $58 \%$ per investigators' assessment, respectively. Responses were durable, with $39 \%$ of patients maintaining the response at a median follow-up of 27.1 months, including 37\% with persistent CR. Of note, CAR T-cell expansion after infusion was significantly associated with response. The median duration of progression-free survival (PFS) was 5.9 months, with PFS rates of $49 \%$ at 6 months and $41 \%$ at 15 months. Median OS was not reached, with an estimated 24-month OS rate of 50.5\% and two responding patients underwent allo-HSCT. Globally, 95\% of patients developed grade $\geq 3$ AEs. A total of $93 \%$ of patients experienced CRS, $13 \%$ of grade $3 / 4$, including a death related to hemophagocytic lymphohistiocytosis (HLH). NTX occurred in $64 \%$ of patients, $28 \%$ being grade $\geq 3(22,24,25)$.

JULIET (CCTL019-C2201) was the multicenter single-arm pivotal phase II clinical trial that led to the FDA-approval of tisagenlecleucel for adult patients with R/R DLBCL (26). The trial enrolled 165 patients, of whom 111 were infused and 93 were evaluated for clinical response. Patients had received at least two prior lines of therapy and $54 \%$ had failed a prior autologous HSCT. The median time from enrollment to infusion was 54 days and the majority of patients (92\%) received a bridging therapy to keep hematological disease under control. Patients received after lymphodepleting chemotherapy in $93 \%$ of cases - a median CAR T-cell dose of $3.1 \times 10^{8}$ (range 0.6-6.0). The median followup for data cutoff was 14 months. Best ORR was 52\%, with 
$40 \%$ of $\mathrm{CR}$ and $12 \%$ of partial response (PR). Among patients with $\mathrm{CR} / \mathrm{PR}$ as best response $(n=48)$, the relapse-free survival (RFS) was $65 \%$ at 12 months. At 12 months, OS was $40 \%$. Grade $3 / 4$ CRS rate was $22 \%$, and globally $24 \%$ of the patients were admitted to the ICU for CRS management. NTX developed in $21 \%$ of patients, with $12 \%$ of the cases being of grade $3 / 4$, without fatalities.

\section{Additional Studies on CD19-Targeting CARs in B-ALL and B-NHL}

ROCKET was a multicenter single-arm phase II clinical trial testing the CD28 construct JCAR015, developed by Juno Therapeutics. The study enrolled 38 adult patients with R/R BALL and, after a median follow-up of 12.9 months, median EFS and OS were 4.4 and 8.1 months, respectively. CRS was observed in $27 \%$ of the cases and $29 \%$ of the patients experienced grade 3/4 NTX. Following several episodes of cerebral edema, some of which were fatal, the trial was halted by FDA. After a thorough analysis, investigators concluded that a surge in inflammatory cytokine levels from rapid, early T-cell proliferation may have provoked the blood-brain barrier (BBB) disruption seen in these patients, inducing fatal cerebral edema (27). However, the precise underlying cause remains unknown.

TRANSCEND-001 was the first-in-human study testing the second-generation CD19-BBz product JCAR017 (lisocabtagene maraleucel, liso-cel), developed by Juno Therapeutics and characterized by a defined ratio of 1:1 CD8+ and CD4+ CAR $\mathrm{T}$ cells. This multicenter phase I clinical trial enrolled patients with R/R aggressive B-NHL, and the results of the DLBCL cohort (including also cases transformed from indolent lymphomas, high-grade B-cell lymphomas with MYC and BCL2 and/or BCL6 rearrangements, PMBCL and grade $3 \mathrm{~B} F L$ ) were presented at 2019 American Society of Hematology meeting. A total of 342 patients were leukapheresed and 268 ones received liso-cel, at 3 different dose levels. The dose of $100 \times 10^{6}$ viable CAR T cells was chosen for dose confirmation and thus administered in the majority of patients $(n=176)$. Among the 256 heavily pretreated patients evaluable for efficacy, $34 \%$ of whom received a prior autologous-HSCT, ORR was $73 \%$, with $53 \%$ of patients achieving a CR. After a median follow-up of 12 months, median duration of response (DOR) was not reached and PFS and OS were estimated at 6.8 and 21.1 months, respectively. In this large clinical trial, liso-cel demonstrated clinical activity across different subgroups, including patients with high-risk prognostic features. Regarding safety profile, CRS developed in $42 \%$ and NTX in $30 \%$ of patients, including $2 \%$ grade $3 / 4$ CRS and $10 \%$ grade $3 / 4$ NTX. Prolonged grade $3 / 4$ cytopenias were reported in $37 \%$ of patients. Globally, seven deaths were recorded, 4 of which considered to be related to liso-cel (28).

ZUMA-2 is a multicenter phase II trial which evaluated KTE$\mathrm{X} 19$, a product which shares the same design of axi-cel but which is obtained in a different manufacturing process removing CD19-positive malignant cells, in patients with $\mathrm{R} / \mathrm{R}$ mantle cell lymphoma (MCL). Seventy-four patients were enrolled, and the product was administered to 68 ones. ORR and CR rate were 93 and $67 \%$ in the primary efficacy analysis involving the first 60 infused patients, and 85 and $59 \%$ by intention-totreat, respectively. After a median follow-up of 12.3 months, the estimated 12 months PFS and OS were 61 and $83 \%$ in the primary efficacy analysis populations. Cytopenias occurred in $94 \%$ of the patients and grade $3 / 4$ CRS and NTX in 15 and $31 \%$ of the cases, respectively. Two grade 5 infectious adverse events were recorded (29).

ZUMA-3 is a phase I/II trial evaluating KTE-X19 in adult patients with R/R B-ALL (NCT02614066) (30). Until now, only the phase I results have been reported. After a median followup of 16 months, 45 patients had received KTE-X19, 66\% of which had received $\geq 3$ prior lines of therapy. There were 2 reported KTE-X19-related grade 5 AEs (cerebral infarction and multiorgan failure), both in the context of CRS. CRS and NTX of grade $\geq 3$ occurred in 29 and $38 \%$ of the patients, respectively. Of 41 patients with a follow-up $\geq 2$ months, $68 \%$ achieved CR/CR with incomplete count recovery (CRi) and $73 \%$ reached undetectable MRD. With the limitation of small patient numbers and the presence of some confounding factors, prior blinatumumab treatment did not seem to jeopardize the manufacturing process or affect clinical results (31). The phase II of the trial is currently ongoing at the $1 \times 10^{6}$ infusion dose and with revised adverse event management recommendations. Another phase I/II trial (ZUMA-4, NCT02625480) is evaluating axicabtagene ciloleucel in pediatric/adolescent patients with $\mathrm{R} / \mathrm{R}$ B-ALL (32).

Mature data on an autologous CD19-28z CAR T-cell construct completely manufactured at MSKCC (NTC01044069) in relapsed B-ALL adult patients were reported by Park and colleagues (33). Fifty-three patients received CAR T cells and CR was obtained in $83 \%$ of the cases. After a median follow-up of 29 months, median EFS and OS were 6.1 and 12.9 months, respectively. Patients with $<5 \%$ bone marrow blasts before treatment had an improved remission duration and survival, with median EFS and OS of 10.6 and 20.1 months, respectively. After infusion, severe CRS occurred in 14 patients and was fatal in one of them. Patients without morphological marrow remission before treatment, higher burden of disease or extra-medullary disease had a greater incidence of CRS, NTX, and shorter longterm survival.

The field of anti-CD19 CAR T-cell development in B-NHL and B-ALL is rapidly expanding, with several additional studies being recently reported (34-39), and more than 100 clinical trials currently registered worldwide. Comparing the results of these studies is becoming increasingly complex, given the differences in patient population, bridging therapy and toxicity grading system employed. Selected clinical trial results in B-ALL and B-NHL are summarized in Tables 1, 2.

\section{CAR T-CELL TOXICITY}

\section{Cytokine Release Syndrome Diagnosis and Management}

CRS is the most frequent $\mathrm{AE}$ associated with CAR T-cell therapy, being described in 50-90\% of the patients in major clinical trials $(21,22,24-26)$, and most commonly occurring within the first 
TABLE 1 | Selected clinical trials of CAR T cells in B-cell acute lymphoblastic leukemia

\begin{tabular}{|c|c|c|c|c|c|c|c|c|c|c|c|c|c|}
\hline Setting & Target & Product & $\begin{array}{l}\text { Costimul. } \\
\text { domain }\end{array}$ & Generation & Vector & $\begin{array}{l}\text { Population } \\
\text { infused }\end{array}$ & Response & $\begin{array}{l}\text { Durable remission } \\
\text { rate }\end{array}$ & $\begin{array}{l}\text { CRS } \\
\text { (gr.3/4) }\end{array}$ & $\begin{array}{l}\text { NTX } \\
\text { (gr.3/4) }\end{array}$ & $\begin{array}{l}\text { Institute/ } \\
\text { Company }\end{array}$ & Clinical trial & References \\
\hline \multirow[t]{10}{*}{ B-ALL } & CD19 & $\begin{array}{l}\text { Tisagenlecleucel } \\
\text { (CTL019, } \\
\text { Kymriah }^{\circledR} \text { ) }\end{array}$ & $4-1 \mathrm{BB}$ & Second (2nd) & Lentiviral & $\begin{array}{l}75, \mathrm{R} / \mathrm{R} \\
\text { pediatric/AYA } \\
\text { B-ALL } \\
\text { (up to } 25 \text { yo) }\end{array}$ & $\begin{array}{l}\text { ORR } 81 \% \\
\text { CR } 60 \%\end{array}$ & $\begin{array}{l}\text { RFS } \\
80 \% \text { at } 6 \mathrm{mo} \\
59 \% \text { at } 12 \mathrm{mo}\end{array}$ & $47 \%{ }^{¥}$ & $13 \%^{ \pm}$ & UPenn/Novartis & $\begin{array}{l}\text { ELIANA } \\
\text { NCT02435849 } \\
\text { multicenter } \\
\text { phase II }\end{array}$ & (21) \\
\hline & & KTE-X19 & CD28 & Second (2nd) & Retroviral & $\begin{array}{l}\text { 45, R/R adult } \\
\text { B-ALL }\end{array}$ & $\begin{array}{l}\text { ORR 82\% } \\
\text { CR 73\% }\end{array}$ & $\begin{array}{l}\text { Median DOR } \\
12.9 \mathrm{mo}\end{array}$ & $29 \% \$$ & $38 \%^{ \pm}$ & Kite, Gilead & $\begin{array}{l}\text { ZUMA-3 } \\
\text { NCT02614066 } \\
\text { multicenter } \\
\text { phase I/II }\end{array}$ & (30) \\
\hline & & & & & & $\begin{array}{l}\text { 24, R/R } \\
\text { pediatric/AYA } \\
\text { B-ALL }\end{array}$ & $\begin{array}{l}\text { CR + CRi rate } \\
64-100 \% \\
\text { (related to } \\
\text { CART dose) }\end{array}$ & $\begin{array}{l}\text { ongoing remission } \\
25-56 \% \text { (related to } \\
\text { CART dose) }\end{array}$ & $\begin{array}{l}22-75 \% \%^{\S} \text { (related } \\
\text { to CART dose) }\end{array}$ & $\begin{array}{l}11-36 \%^{ \pm} \text {(related } \\
\text { to CART dose) }\end{array}$ & & $\begin{array}{l}\text { ZUMA-4 } \\
\text { NCT02625480 } \\
\text { Multicenter } \\
\text { phase I/II }\end{array}$ & (32) \\
\hline & & 19-28z-CAR & CD28 & Second (2nd) & Retroviral & $\begin{array}{l}53, \mathrm{R} / \mathrm{R} \text { adult } \\
\text { B-ALL }\end{array}$ & CR 83\% & Unknown & $26 \% \pi$ & $42 \%^{ \pm}$ & MSKCC/Juno & $\begin{array}{l}\text { NCT01044069 } \\
\text { Phase I }\end{array}$ & (33) \\
\hline & & CD19-28z-CAR & CD28 & Second (2nd) & Retroviral & $\begin{array}{l}\text { 19, R/R } \\
\text { pediatric/AYA } \\
\text { B-ALL } \\
\text { (up to } 30 \text { yo) }\end{array}$ & CR 67\% & 12-mo LFS 78.8\% & $28 \%^{ \pm}$ & $5 \%\urcorner$ & $\mathrm{NCl}$ & $\begin{array}{l}\text { NCT01593696 } \\
\text { Phase I }\end{array}$ & (40) \\
\hline & & $\begin{array}{l}\mathrm{CD}^{+} / \mathrm{CD}^{+} \\
\mathrm{CD} 19-\mathrm{BBz}-\mathrm{CAR}\end{array}$ & $4-1 \mathrm{BB}$ & Second (2nd) & Lentiviral & $\begin{array}{l}\text { 45, R/R } \\
\text { pediatric/AYA } \\
\text { B-ALL }\end{array}$ & $\mathrm{MRD}^{-} \mathrm{CR} 89 \%$ & Unknown & $23 \%^{ \pm}$ & $21 \%^{ \pm}$ & $\mathrm{SCH}$ & $\begin{array}{l}\text { PLAT-02 } \\
\text { NCT02028455 } \\
\text { Phase I/II }\end{array}$ & (41) \\
\hline & & $\begin{array}{l}\text { CD19- } \\
\text { BBz.EGFRt-CAR }\end{array}$ & $4-1 \mathrm{BB}$ & Second (2nd) & Lentiviral & $\begin{array}{l}\text { 30, R/R adult } \\
\text { B-ALL }\end{array}$ & $\begin{array}{l}\text { CR 93\% } \\
\text { MRD neg 86\% }\end{array}$ & Unknown & $23 \% \S$ & $50 \%^{ \pm}$ & FHCRC & $\begin{array}{l}\text { NCT01865617 } \\
\text { Phase I/II }\end{array}$ & (42) \\
\hline & & UCART19 & $4-1 \mathrm{BB}$ & $\begin{array}{l}\text { Allogeneic } \\
\text { CAR T cells, } \\
\text { gene editing } \\
\text { with TALEN }\end{array}$ & Lentiviral & $\begin{array}{l}\text { 7, R/R pediatric } \\
\text { B-ALL }\end{array}$ & $\begin{array}{l}\text { CR + CRi 88\% } \\
\text { MRD neg } 86 \%\end{array}$ & $\begin{array}{l}\text { Ongoing remission } \\
28 \%\end{array}$ & $15 \%^{+}$ & $0 \%^{+}$ & $\begin{array}{l}\text { MDACC, UCL } \\
\text { etc./Servier }\end{array}$ & $\begin{array}{l}\text { PALL } \\
\text { NCT02808442 } \\
\text { Phase I }\end{array}$ & (43) \\
\hline & & & & & & $\begin{array}{l}\text { 13, R/R } \\
\text { Adult B-ALL }\end{array}$ & & $\begin{array}{l}\text { Ongoing remission } \\
21 \%\end{array}$ & & & & $\begin{array}{l}\text { CALM } \\
\text { NCT02746952 } \\
\text { Phase I }\end{array}$ & \\
\hline & CD22 & CD22-BBz-CAR & $4-1 \mathrm{BB}$ & Second (2nd) & Lentiviral & $\begin{array}{l}\text { 21, R/R } \\
\text { pediatric/adult } \\
\text { B-ALL }\end{array}$ & CR 73\% & $\begin{array}{l}\text { Median DOR } \\
6 \mathrm{mo}\end{array}$ & $0 \%^{ \pm}$ & $0 \%^{ \pm}$ & $\mathrm{NIH}$ & $\begin{array}{l}\text { NCT02315612 } \\
\text { Phase I }\end{array}$ & (44) \\
\hline
\end{tabular}

$¥$ ¥, Penn/CHOP grading scale; §, NCl 2014 consensus grading scale modified by Lee DW et al. (45); "II, MSKCC criteria; ᄀ, CTCAE v4.02;, \pm CTCAE V4.03; ${ }^{\dagger}$ CTCAE v5.0.

ALL, acute lymphoblastic leukemia; R/R, relapse/refractory; AYA, adolescent and young adult; ORR, overall response rate; CR, complete remission; CRi, complete remission with incomplete hematologic recovery; MRD, minimal residual disease; mo, months; DOR, duration of response; EFS, event-free survival; RFS, relapse-free survival; LFS, leukemia-free survival; DFS, disease-free survival; NR, not reached; CRS, cytokine release syndrome; NTX, neurotoxicity; UPenn, University of Pennsylvania Hospital; SCH, Seattle Children's Hospital; FHCRC, Fred Hutchinson Cancer Research Center; MSKCC, Memorial Sloane Kettering Cancer Center; NCI, National Cancer Institute; MDACC, MD Anderson Cancer Center; UCL, University College of London. 
TABLE 2 | Selected clinical trials of CAR T cells in B-cell non-Hodgkin lymphomas and chronic lymphocytic leukemia.

\begin{tabular}{|c|c|c|c|c|c|c|c|c|c|c|c|c|c|}
\hline Setting & Target & Product & $\begin{array}{l}\text { Costimul. } \\
\text { domain }\end{array}$ & Generation & Vector & Population infused & Response & $\begin{array}{l}\text { Durable remission } \\
\text { rate }\end{array}$ & $\begin{array}{l}\text { CRS } \\
\text { (gr.3/4) }\end{array}$ & $\begin{array}{l}\text { NTX } \\
\text { (gr.3/4) }\end{array}$ & $\begin{array}{l}\text { Institute/ } \\
\text { Company }\end{array}$ & Clinical trial & Reference \\
\hline \multirow[t]{8}{*}{$\begin{array}{l}\text { B-cell } \\
\mathrm{NHL}\end{array}$} & \multirow[t]{6}{*}{ CD19 } & $\begin{array}{l}\text { Axicabtagene } \\
\text { ciloleucel } \\
\text { (KTE- } \\
\text { C19, Yescarta }{ }^{\circledR} \text { ) }\end{array}$ & CD28 & Second (2nd) & Retroviral & $\begin{array}{l}\text { 108, R/R DLBCL, } \\
\text { PMBCL, t-FL }\end{array}$ & $\begin{array}{l}\text { ORR } 83 \% \\
\text { CR } 58 \%\end{array}$ & $\begin{array}{l}\text { Median DOR } \\
11.1 \mathrm{mo}\end{array}$ & $11 \%^{\S}$ & $32 \%^{ \pm}$ & $\mathrm{NCl} /$ Kite, Gilead & $\begin{array}{l}\text { ZUMA-1 } \\
\text { NCT02348216 } \\
\text { multicenter phase I/II }\end{array}$ & (25) \\
\hline & & KTE-X19 & & & & 68, R/R MCL & $\begin{array}{l}\text { ORR 93\% } \\
\text { CR } 67 \%\end{array}$ & Unknown & $15 \% \S$ & $31 \%^{ \pm}$ & & $\begin{array}{l}\text { ZUMA-2 } \\
\text { NCT02601313 } \\
\text { multicenter phase II }\end{array}$ & (29) \\
\hline & & $\begin{array}{l}\text { Tisagenlecleucel } \\
\text { (CTL019, } \\
\text { Kymriah }^{\circledR} \text { ) }\end{array}$ & $4-1 \mathrm{BB}$ & Second (2nd) & Lentiviral & $\begin{array}{l}\text { 111, R/R } \\
\text { DLBCL, t- FL }\end{array}$ & $\begin{array}{l}\text { ORR } 52 \% \\
\text { CR } 40 \%\end{array}$ & 12-mo RFS 65\% & $22 \% ¥$ & $12 \%^{ \pm}$ & UPenn/Novartis & $\begin{array}{l}\text { JULIET } \\
\text { NCT02445248 } \\
\text { Multicenter phase lla }\end{array}$ & (26) \\
\hline & & $\begin{array}{l}\text { Lisocabtagene } \\
\text { maraleucel } \\
\text { (JCAR017) }\end{array}$ & $4-1 \mathrm{BB}$ & Second (2nd) & Lentiviral & $\begin{array}{l}\text { 269, R/R DLBCL, } \\
\text { t-FL, } \\
\text { PMBCL, FL3B, } \\
\text { HGBCL }\end{array}$ & $\begin{array}{l}\text { ORR 73\% } \\
\text { CR 53\% }\end{array}$ & $\begin{array}{l}\text { 12-mo DOR } \\
54.7 \%\end{array}$ & $2 \% \$$ & $10 \%^{ \pm}$ & $\begin{array}{l}\text { FHCRC/Juno, } \\
\text { Celgene }\end{array}$ & $\begin{array}{l}\text { TRANSCEND-001 } \\
\text { NCTO2631044 } \\
\text { Multicenter phase I }\end{array}$ & (28) \\
\hline & & $\begin{array}{l}\text { Lisocabtagene } \\
\text { maraleucel } \\
\text { (JCAR017) } \\
\text { + Durvalumab }\end{array}$ & 4-1BB & Second (2nd) & Lentiviral & $\begin{array}{l}11, \mathrm{R} / \mathrm{R} \\
\mathrm{B}-\mathrm{NHL}\end{array}$ & $\begin{array}{l}\text { ORR } 91 \% \\
\text { CR } 64 \%\end{array}$ & Unknown & Unknown & Unknown & Celgene/Juno & $\begin{array}{l}\text { PLATFORM } \\
\text { NCT03310619 } \\
\text { Phase I/II }\end{array}$ & (46) \\
\hline & & $\begin{array}{l}\text { JCAR014 + } \\
\text { Durvalumab }\end{array}$ & $4-1 \mathrm{BB}$ & Second (2nd) & Lentiviral & $\begin{array}{l}\text { 15, R/R } \\
\text { Aggressive B-NHL }\end{array}$ & ORR $50 \%$ & $\begin{array}{l}\text { Ongoing remission } \\
33 \%\end{array}$ & $7 \% \S$ & $0 \%^{ \pm}$ & $\begin{array}{l}\text { FHCRC/Juno, } \\
\text { Medlmmune }\end{array}$ & $\begin{array}{l}\text { NCT02706405 } \\
\text { Phase lb }\end{array}$ & $(47)$ \\
\hline & \multirow[t]{2}{*}{ CD20 } & CD20-CAR & None & First (1st) & Plasmidic & $\begin{array}{l}\text { 7, R/R } \\
\text { Indolent NHL, MCL }\end{array}$ & $\begin{array}{l}\text { ORR 43\% } \\
\text { CR 28\% }\end{array}$ & $\begin{array}{l}\text { Median DOR } \\
5 \mathrm{mo}\end{array}$ & $0 \%{ }^{\circ}$ & $0 \%{ }^{\circ}$ & FHCRC & $\begin{array}{l}\text { NCT00012207 } \\
\text { Phase I }\end{array}$ & (48) \\
\hline & & $\begin{array}{l}\text { scFvFc.CD28- } \\
\text { CD137z }\end{array}$ & $\begin{array}{l}\mathrm{CD} 28 \\
4-1 \mathrm{BB}\end{array}$ & Third (3rd) & Plasmidic & $\begin{array}{l}3, \mathrm{R} / \mathrm{R} \\
\text { indolent } \mathrm{NHL}, \mathrm{MCL}\end{array}$ & $\begin{array}{l}\text { ORR 100\% } \\
\text { CR } 67 \% \\
\text { PR } 33 \%\end{array}$ & Unknown & $0 \%$ & $0 \%{ }^{\circ}$ & FHCRC & $\begin{array}{l}\text { NCT00621452 } \\
\text { Phase I }\end{array}$ & (49) \\
\hline \multirow[t]{4}{*}{ CLL } & \multirow[t]{4}{*}{ CD19 } & $\begin{array}{l}\text { Tisagenlecleucel } \\
\text { (CTL019, } \\
\text { Kymriah }^{\circledR} \text { ) }\end{array}$ & $4-1 \mathrm{BB}$ & Second (2nd) & Lentiviral & 14, R/R CLL/SLL & $\begin{array}{l}\text { ORR } 57 \% \\
\text { CR 29\% }\end{array}$ & Unknown & $43 \%{ }^{¥}$ & $7 \%^{\circ}$ & UPenn/Novartis & $\begin{array}{l}\text { NCT01029366 } \\
\text { Phase I }\end{array}$ & (14) \\
\hline & & $\begin{array}{l}\text { Lisocabtagene } \\
\text { maraleucel } \\
\text { (JCAR017) }\end{array}$ & $4-1 \mathrm{BB}$ & Second (2nd) & Lentiviral & 23, R/R CLL/SLL & $\begin{array}{l}\text { ORR } 81 \% \\
\text { CR } 45 \%\end{array}$ & Unknown & $9 \% §$ & $22 \%^{ \pm}$ & Juno, Celgene & $\begin{array}{l}\text { TRANSCEND-CLL- } \\
004 \text { NCT03331198 } \\
\text { Phase I/II }\end{array}$ & (50) \\
\hline & & $\begin{array}{l}\text { CTL119.BBz-CAR } \\
+ \text { Ibrutinib }\end{array}$ & 4-1BB & Second (2nd) & Lentiviral & $19, \mathrm{r} / \mathrm{r} \mathrm{cll}$ & $\begin{array}{l}\text { ORR } 71 \% \\
\text { CR } 43 \%\end{array}$ & $\begin{array}{l}\text { Ongoing remission } \\
53 \% \text { at } 12 \mathrm{mo} \mathrm{MRD}^{-} \\
37 \%)\end{array}$ & $16 \%^{¥}$ & $5 \%^{ \pm}$ & UPenn & $\begin{array}{l}\text { NCT02640209 } \\
\text { Pilot trial }\end{array}$ & (51) \\
\hline & & $\begin{array}{l}\text { CD19- } \\
\text { BBz.EGFRt-CAR }\end{array}$ & $4-1 \mathrm{BB}$ & Second (2nd) & Lentiviral & $\begin{array}{l}24, r / r \text { cll } \\
\text { Post-ibrutinib } \\
\text { (5 richter, 25\% } \\
\text { post -venetoclax) }\end{array}$ & $\begin{array}{l}\text { ORR 71\% } \\
\text { CR 21\% } \\
\text { MRD neg 58\% }\end{array}$ & Unknown & $25 \% \S$ & $25 \%^{ \pm}$ & FHCRC & $\begin{array}{l}\text { NCT01865617 } \\
\text { Phase I/II }\end{array}$ & (52) \\
\hline
\end{tabular}

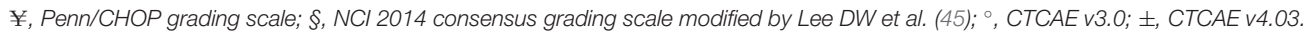

NHL, non-Hodgkin lymphoma; DLBCL, diffuse large B-cell lymphoma; $t$-FL, transformed follicular lymphoma; FL3B, grade 3B follicular lymphoma; MCL, mantle cell lymphoma; PMBCL, primary mediastinal B-cell lymphoma; HGBCL, high-grade B-cell lymphoma; CLL/SLL, chronic lymphocytic leukemia/small lymphocytic lymphoma; R/R, relapse/refractory; ORR, overall response rate; CR, complete remission; PR, partial response; MRD, minimal residual disease; DOR, duration of response; OS, overall survival; PFS, progression-free survival; RFS, relapse-free survival; CRS, cytokine release syndrome; NTX, neurotoxicity; UPenn, University of Pennsylvania Hospital; FHCRC, Fred Hutchinson Cancer Research Center; NCI, National Cancer Institute. 
days after product infusion. CRS is a systemic inflammatory condition, which originates from direct activation and expansion of $\mathrm{T}$ cells after the interaction with target cells, leading to the production of cytokines such as TNF-alpha and INF-gamma. Besides, activated macrophages are the main responsible for IL6 and IL-1 secretion, an essential event for CRS progression (53, 54). Furthermore, activated endothelial cells appear particularly important for the development of severe CRS.

CRS could range from a self-limiting flu-like syndrome to a life threatening multi-organ dysfunction, requiring immediate intervention and intensive life-supporting treatments. The CRSassociated capillary leak syndrome can lead to hypotension, reduced renal blood flow and pulmonary edema. Besides, it can be accompanied by clinical and/or laboratory evidence of macrophage activation, or even turn into a full-blown HLH (55), and specific criteria for the diagnosis of for CAR Tcell-related HLH/macrophage activation syndrome have been proposed (56). A reliable way to evaluate CRS is of utmost importance, in order to weight the incidence and the severity of CRS, but the comparison of different products and trials has been complicated by the lack of a uniform grading system $(14,45,56)$. To overcome this issue, a consensus grading system for CRS and NTX associated with immune effector cell therapies has been recently proposed by the American Society for Transplantation and Cellular Therapy (ASTCT) (57).

Along with aggressive supportive measures usually in the contest of an ICU, severe CRS management requires the use of direct cytokine inhibition. The FDA-approved drug tocilizumab - an IL-6 receptor antagonist - is currently employed as first line treatment for CRS (usually $\geq$ G2) and is also under investigation as a prophylactic strategy (58). For patients with an unsatisfactory response, second line relies on systemic corticosteroids. In this regard, recent data showed that early therapeutic intervention at the first signs of CRS - including the use of corticosteroids - can prevent serious complications without affecting clinical results, mitigating the fear that these drugs could hamper CAR T-cell efficacy $(59,60)$. Although in some centers corticosteroids are now commenced early, possibly at the same time as tocilizumab (61), the aforementioned results might not be valid for all CAR T-cell products, and the best dose and duration of corticosteroids treatment remains to be defined.

Additional cytokine antagonist agents (e.g., the anti-IL-6 siltuximab, the TNF inhibitor etanercept, and the anti-IL-1 receptor anakinra) $(4,56,62)$ or ibrutinib, as suggested in a preclinical model (63), may represent further options in refractory cases. Recently, the tyrosine-kinase inhibitor dasatinib was shown to suppresses CAR T-cell cytotoxicity, cytokine secretion, and proliferation, thus suggesting a potential role of this drug in the treatment of CRS $(64,65)$.

A standardized CRS management strategy has been hard to define, due to different grading systems and CAR T-cell products tested in clinical trials, and proposing recommendations for the best approach in refractory cases is even harder, given the small number of patients who received each treatment and the incomplete understanding of the pathogenesis of CRS.
Finally, alternative strategies to optimize safety without compromising efficacy of CAR T-cell therapy, such as fractionated intrapatient dosing, are also being developed (66).

\section{Neurotoxicity Diagnosis and Management}

NTX is the second most frequent serious $\mathrm{AE}$, and it has been specifically defined with the term "CAR T-cell-related encephalopathy syndrome" (CRES) (56) or the broader "immune effector cell-associated neurotoxicity syndrome" (ICANS) (57). ICANS can occur in the contest of CRS, and severe NTX is more frequent in patients with severe CRS (67); however, the two events are not directly related, since neurologic symptoms often do not develop simultaneously, starting sometimes before CRS or even after CRS resolution (55).

Severe ICANS is characterized by endothelial activation and increased BBB permeability, leading to high concentration of inflammatory cytokines in the cerebrospinal fluid (CSF). Consequently, brain vascular pericyte stress and further secretion of endothelium-activating cytokines cause a further increase in BBB permeability, in a vicious cycle (67). Moreover, in a preclinical macaque model both CAR and non-CAR T cells could accumulate in the CSF and in the brain parenchyma, suggesting their direct role in NTX development (68).

ICANS usually manifests with impaired attention, language disturbance, confusion, and disorientation. Headache, tremors, agitation, hallucination, and aphasia can also occur. More rarely and in severe cases, seizures, motor weakness, increased intracranial pressure, and cerebral edema may be present. The more recent grading system of NTX employs a 10-point scoring system following the Immune Effector Cell-Associated Encephalopathy (ICE) assessment tool and it considers five main neurological domains (57).

Patients with severe ICANS should be managed aggressively and a multidisciplinary approach is often necessary, including neurologic consultation. Electroencephalogram, brain magnetic resonance, and CSF examination are important in the work-up of a suspected ICANS to rule out other causes of NTX $(56,67)$. Levetiracetam can be used as a prophylactic strategy to prevent seizures, beginning on the day of CAR T-cell infusion, or it can be started at the first sign of NXT. First line treatment for NTX usually consists of corticosteroids, mainly dexamethasone or high dose methylprednisolone. Tocilizumab is used when concomitant CRS occurs, but its role for NTX treatment is less clear, given its inability to cross BBB and its possible capability to increase IL-6 levels in CSF, reason why the antiIL-6 drug siltuximab is emerging as an effective alternative $(56,69)$. Recently, granulocyte-macrophage colony-stimulating factor (GM-CSF) was shown to be an important player in the pathogenesis of NTX, and the humanized monoclonal antibody anti-GM-CSF lenzilumab was able to effectively prevent CD19CAR-induced neuroinflammation and CRS in preclinical models (70). A clinical trial testing lenzilumab with axi-cel in R/R DLBCL will soon be open for enrollment (NCT04314843).

Albeit life-threatening in some instances, including a few fatal episodes (67), ICANS is completely reversible alike CRS in the vast majority of cases, and most patients have a selflimited course. 


\section{Additional Side Effects}

Infusion reactions are usually mild and tumor lysis syndrome (TLS) is uncommon but can occur in patients with high tumor burden: both should be managed according to standard guidelines (62). Prolonged B-cell aplasia is very common and it is a marker of CAR T-cell persistence (14). The resulting hypogammaglobulinemia can be corrected with intravenous immunoglobulin replacement therapy. Severe pancytopenia is extremely common and can last several weeks after CAR T-cell infusion, in up to $30 \%$ of the cases persisting beyond day 30 . Late hematological toxicity has been associated with high grade CRS and a recent stem cell transplantation (71). Cytopenia can be managed with growth factors and antifungal prophylaxis can be considered for prolonged neutropenia. Especially for patients receiving fludarabine-containing lymphodepleting regimens, a prolonged prophylaxis for pneumocystis jirovecii pneumonia and herpes zoster reactivation is recommended (69).

\section{Clinical Risk Factors and Biomarkers for CAR T-Cell-Related Toxicity}

CAR T-cell-induced CRS and NTX pathophysiology currently remains poorly understood and risk factors for toxicity development have been mostly defined in the context of human studies.

First, investigators tried to identify clinical factors promoting CAR T-cell expansion, since high CAR T-cell peak counts in patients with CD19-positive lymphoid malignancies have been consistently correlated with the development of severe CRS $(16,40,72,73)$ and NTX $(22,73)$. High pre-treatment tumor burden is a major driver of CAR T-cell in vivo propagation and B-ALL patients developing severe CRS had a significantly higher baseline bone marrow blast count compared to those who developed lower-grade or no CRS $(16,62,74)$. Globally, trials including patients with ALL reported higher rate of severe CRS compared to NHL ones $(21,22,26,30,33)$, and this may be due to higher tumor burden, different disease distribution and more proliferative nature of ALL compared to NHL (75). Similar to severe CRS, TLS, and severe neurotoxic effects secondary to CAR T-cell infusion have been found to prevalently occur in individuals with greater tumor burden $(33,41,56,67)$.

Besides, in two studies investigating the clinical effects of antiCD19 CAR T-cell products with defined CD4:CD8 ratio in R/R BALL (42) and NHL (73), Turtle and coworkers observed superior CAR T-cell peak levels in individuals receiving higher (i.e., $2 \times$ $10^{6}$ vs. $2 \times 10^{5} / \mathrm{kg}$ ) CAR T-cell dose, likely accounting for the correlation between numbers of infused CAR T-cell and severe toxicity $(40,41,76)$. Notably, disease burden and CAR T-cell dose have a synergistic, positive effect on CAR T-cell expansion. Thus, adapting CAR T-cell dose to disease burden, rather than defining an individual fixed dose for all patients, might optimize efficacy and safety in each case.

The co-stimulatory domain also play an important role, since $28 \mathrm{z}$ CAR T cells show superior and more rapid expansion compared to $\mathrm{BBz}$ ones (55); besides, $\mathrm{T}$ cells expressing CARs with hinge and transmembrane domains from the CD8-alpha molecule release significantly lower levels of cytokines in vitro compared to those derived from CD28 (77).

Combined cyclophosphamide/fludarabine (Cy/Flu) conditioning also improves expansion and persistence of CAR T cells, as opposed to single-agent cyclophosphamide $(42,73)$, presumably due to its intensified depleting effect on recipient lymphocytes (78). Consistent with this hypothesis, $\mathrm{Cy} / \mathrm{Flu}$ has been found to be an independent predictor of severe CRS and ICANS post-CAR T-cell infusion $(67,76,78)$.

Several biomarkers have been correlated with CRS and/or NTX development, such as LDH, ferritin, CRP, inflammatory cytokines, GM-CSF, von Willebrand Factor, and angiopoietin 2 (reflecting endothelia activation) and lower platelet count, but a definitive predictive model is still lacking $(22,67,76,79-82)$.

\section{IMPROVING CAR T-CELL EFFICACY}

\section{Mechanisms of Resistance to CAR T-Cell Therapy}

Clinical experience with anti-CD19 CAR T cells has identified two main causes of resistance or disease relapse: (1) the presence or appearance of antigen-negative tumor cells, and (2) intrinsic characteristics of effector $\mathrm{T}$ cells which limit their function and efficacy (i.e., antigen-positive relapses) (83).

Approximately $30 \%$ of pediatric and young adult B-ALL patients treated with anti-CD19 CAR $\mathrm{T}$ cells relapse with a CD19-negative disease (21), and CD19 loss and downregulation has been observed in the NHL setting as well (84). Indeed, in ZUMA-1 trial $33 \%$ of the patients with available post-relapse samples showed loss of CD19 expression (85). It is still unclear whether these CD19-negative cells are present in the initial cancer and overgrow thanks to a selective advantage under the pressure exerted by T-cell therapy, or if they result from de novo mutations. The lack of CD19 surface expression may be due to mutations or alternative splicing events $(86,87)$, suggesting the possibility that in some patients the CD19 protein may be truncated, therefore lacking the epitope that is necessary to trigger recognition and killing of tumor cells by CAR T cells and CD19 detection by flow cytometry (88). Preclinical models demonstrated the impact of antigen-loss on the efficacy of CAR T cells also in the setting of solid tumors $(89,90)$. A recent communication by Ruella et al. highlighted a novel rare mechanism of resistance to CAR T-cell therapy, conferred by the accidental transduction of a single leukemic B cell with the anti-CD19 CAR gene during therapy manufacturing (91). The authors showed that the CAR, erroneously expressed on the surface of the neoplastic cell, directly bound CD19-Coexpressed on the same cell-hiding it from recognition and conferring resistance to reprogrammed T cells. An "antidote" to deplete these resistant cells has been recently developed in vitro (92). A further mechanism of CD19-negative immune escape, particularly relevant in MLL-rearranged B-ALL, is lineage switch from lymphoid to myeloid leukemia, with consequent loss of expression of B-lymphoid lineage antigens $(93,94)$.

Alternatively, CAR T-cell treatment failure can be due to antigen-positive relapses, which often occur early after product 
infusion and which may be due several T-cell related mechanisms [reviewed in (95)]. First, poor expansion and early elimination of adoptively transferred CAR $\mathrm{T}$ cells have been almost invariably described in patients who are refractory to the treatment or who relapse in the first months after product infusion (16, 21, 22, 33). Also, reduced anti-tumor activity, anergy and early CAR T-cell exhaustion have been correlated to inferior response rates, especially in CLL (96). Finally, the presence of an immunosuppressive microenvironment can significantly impair the functionality of CAR T cells and represents a major obstacle, especially for their application in solid tumors (see below).

Further improvement in lymphodepleting chemotherapy is currently in progress, with the aim of increasing the magnitude of CAR T-cell expansion and achieving more durable in vivo proliferation. In addition, the design of fully human CAR is under development to limit immune responses against murine-derived scFv and to prolong CAR T-cell in vivo persistence (97). Possible strategies to improve CAR T-cell efficacy are depicted in Figure 2.

\section{Targeting Alternative Antigens in Lymphoproliferative Diseases}

A possible approach to overcome CD19 antigen loss is the targeting of alternative surface antigens, including CD20, CD22, immunoglobulin kappa (k) light chain, CD123, receptor tyrosine kinase-like orphan receptor (ROR1), and CD37, which are currently under evaluation for the treatment of B-cell malignancies (98).
After terrific results obtained with anti-CD20 monoclonal antibodies in B-cell lymphoproliferative diseases, anti-CD20 CAR T-cell therapy has been evaluated, showing enhanced persistence of transduced T cells - including both CD28 and 4$1 \mathrm{BB}$ co-stimulatory domains - and subsequent prolonged PFS in two of three treated patients with indolent B-cell lymphomas or MCL $(48,49)$.

Similarly to CD19, CD22 is also almost uniformly expressed on B cells, and it is currently under evaluation as a target in CD19-negative B-ALL relapses (99, 100). Data from a phase I trial including 21 children and adults with B-ALL infused with anti-CD22 CAR $\mathrm{T}$ cells showed a dose-dependent anti-leukemic activity. A total of 15 patients previously treated with anti-CD19 CAR $\mathrm{T}$ cells were included: CR was obtained in $73 \%$ of the cases, including CD19-negative ones, and median remission duration was 6 months (44). Interestingly, drug-induced CD22 upregulation on leukemic cells could be a promising strategy to improve anti-CD22 CAR T-cell efficacy and remission durability (101).

Immunoglobulin $\mathrm{k}$ light chain antigen is another attractive target, although its expression is limited to a fraction of nonmalignant B cells. On the other side, complete B-cell aplasia can be avoided, thus minimizing long-term humoral immunity impairment. Phase I clinical trials are evaluating efficacy and safety of anti-k light chain CAR T cells in B-NHL, CLL and multiple myeloma (MM) patients (102), with preliminary data showing no significant therapy-related toxicities.

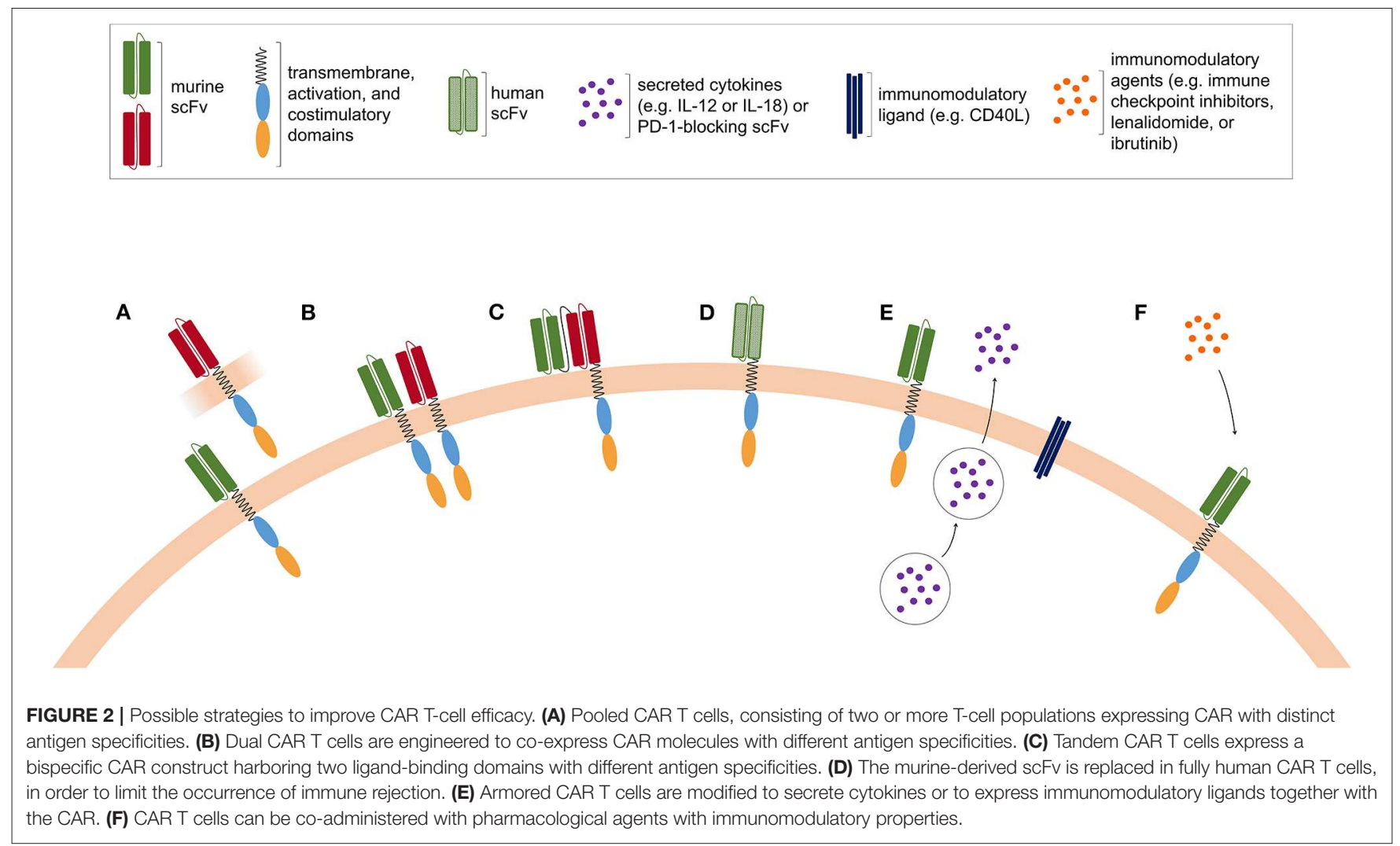


ROR1 is a transmembrane glycoprotein crucial for cell proliferation and survival, constitutionally expressed on embryonal tissue and aberrantly on many adult malignant tissues, including B-cell malignancies (103-106). Humanized monoclonal antibodies, small molecule inhibitors, bispecific T-cell engagers (BiTE), and anti-ROR1 CAR T cells are under development (107-110).

Finally, preclinical studies showed that also anti-CD37 CAR T cells can be active against B-cell lymphomas $(111,112)$.

Despite some promising results, none of the antigens studied so far in B-cell malignancies appears to equal CD19, and the results of ongoing trials will probably clarify their role in future CAR T-cell development.

\section{Targeting Multiple Antigens in Lymphoproliferative Diseases}

A reasonable strategy to successfully avoid antigen-negative relapses in hematologic tumors is to adoptively transfer CAR modified $\mathrm{T}$ cells targeting more than one tumor antigen. This goal may be achieved by administering to patients: (1) two mixed T-cell populations, each transfected with CARs showing different specificities (pooled CAR T cells, Figure 2A); (2) T cells that are engineered to co-express two CARs, each one competent to drive full T-cell activation (dual CAR T cell, Figure 2B); (3) $\mathrm{T}$ cells expressing one single CAR with two binding-domains in frame (tandem-CAR, Figure 2C) (113). Generally, tandemCARs can induce activation of the CAR-expressing $\mathrm{T}$ cells by encountering either one of the two target antigens. Depending on the specific tandem-CAR construct, the binding of the CAR with the two antigens might have different effects on the downstream signaling and T-cell activation. Several pre-clinical studies $(89,90$, $114,115)$ have been published using bi- or tri-specific CARs, all showing that multiple-targeting is highly effective in preventing escape. Ruella et al. reported that targeting CD19 and CD123 on leukemic blasts represents an effective strategy for treating and preventing antigen-loss relapses occurring after CD19-directed therapies (116). Indeed, they devised a dual CAR-expressing construct that combined CD19- and CD123-mediated T-cell activation and demonstrated that it provides superior in vivo activity against B-ALL cells compared to single-expressing CARs or pooled CAR T cells. Other groups analyzed the efficacy of bispecific CAR T cells triggering robust cytotoxicity against target cells expressing either CD19 or CD20 $(117,118)$. Shah et al. recently reported data about a phase I first-in-human trial in $\mathrm{R} / \mathrm{R}$ B-NHL exploring an anti-CD20/anti-CD19 bispecific CAR T-cell construct, with the aim of improving response rates and limiting CD19 negative relapse (118). Additional constructs co-targeting CD19 and CD22 are under development (119).

Globally, data on CAR T cells targeting more than one tumor antigen are still limited, but they are of extreme interest especially in settings in which CD19-negative relapses are more common or in which a specific target antigen is difficult to find (see also section Perspectives in Other Settings).

\section{Combination Therapies}

Combining agents with different mechanisms of action may increase antitumor effect and reduce the risk of resistance
(Figure 2F). As for normal T cells, CAR T-cell activity can be hampered by immune checkpoint proteins, such as programmed death ligand 1 (PD-L1), frequently expressed on tumor cells. Preclinical data have shown that combining CAR $\mathrm{T}$ cells with existing systemic checkpoint blockade antibodies potently enhances the eradication of established tumors (120-123). Thus, the combined use of immune checkpoint inhibitors with CAR $\mathrm{T}$ cells is currently being studied. The association of axi-cel plus atezolizumab is currently being tested in the ZUMA-6 trial (NCT02926833) with encouraging preliminary results (124) and two ongoing studies are evaluating JCAR014 (NCT02706405) (47) and liso-cel (NCT03310619) (46) in combination with another anti-PD-L1 antibody, durvalumab, in patients with relapsed/refractory B-NHL. Sequential approaches are being explored as well, and investigators at the UPenn recently started a phase I/II trial to evaluate the feasibility and efficacy of anti-PD-1 antibody pembrolizumab in patients failing to respond to (or relapsing after) tisa-cel therapy for $\mathrm{B}-\mathrm{NHL}$ (NCT02650999) (125).

Besides, investigators are testing the co-administration of pharmacological agents with immunomodulatory properties, in order to revert immune dysfunctions that characterizes lymphoproliferative diseases, such as CLL and MM. In CLL, tumor cells contribute to generate several defects in innate and adaptive immune system function, which are predictive of a more aggressive disease (126-130). Long-term ibrutinib therapy exerts not only direct anti-tumor activity but also a valuable immunomodulatory effect on different immune cell compartments (131-134). Previous data had already shown that ibrutinib treatment enhances the generation of CAR T cells, and the co-administration of ibrutinib improved the engraftment and therapeutic efficacy of anti-CD19 CAR T cells in CLL and MCL mouse models $(135,136)$. The mechanisms underlying these ibrutinib-induced effects have not been completely clarified, and may be explained by off-tumor effects exerted on different immune compartments, particularly on $\mathrm{T}$ cells, but also by the tumor burden reduction which in turn may mitigate the immunosuppressive signals induced by the neoplastic clone. Based on these preclinical evidences, a prospective clinical trial combining humanized anti-CD19 CAR T cells with ibrutinib in CLL patients not achieving a CR after 6 months of singleagent ibrutinib treatment is currently ongoing at the UPenn (NCT02640209) (51). With similar intents, the administration of lenalidomide and other immunomodulatory drugs (IMIDs) in combination with CAR T cells is under evaluation in the setting of MM (137, 138). Preclinical data showed that lenalidomide combined with second-generation CAR $\mathrm{T}$ cells specific for the CS1 tumor antigen improves anti-myeloma properties and provided the basis to test this combination in the clinical setting (139). Newer agents are also being explored in order to improve expansion and persistence of CAR T cells, such as the 4-1BB agonist utomilumab, currently being tested in the ZUMA-11 trial with axi-cel (NCT03704298).

Combination therapies can also be used to target the tumor microenvironment, and anti-CD123 CAR T cells targeting both Hodgkin lymphoma cells and tumor-associated macrophages showed promising activity in preclinical models (140). 
Oncolytic viruses (OV) have recently received considerable attention due to their potential ability to synergize with cancer immunotherapies. In different preclinical studies, the administration of armed-OV enhanced the immune functions of CAR T cells. OV expressing cytokines have been shown to enhance the survival of tumor-bearing mice by increasing CAR T-cell accumulation in the tumor and modulating its microenvironment $(141,142)$. Alternatively, the expression of a anti PD-L1 "minibody" by an OV could block the PD-1:PDL1 interaction between CAR T cell and tumor cells, resulting in enhanced tumor control (143). Finally, release of BiTEs by an OV enhanced CAR T-cell homing and activation in the tumor, thus enhancing survival and improving efficacy $(144,145)$.

\section{Armored CAR T Cells}

A possible strategy to increase CAR T-cell activity is to endow them with additional functions, aimed at improving tumor infiltration ability, effector functions, reduce immunosuppression, decrease tumor escape, or stimulate the native immune system. These novel engineered $\mathrm{T}$ cells are known as fourth-generation CAR T cells or armored CAR T cells (CAR T cells expressing an additional transgene for enhanced function, Figure 2E).

Commonly, fourth-generation CAR T cells are characterized by the secretion of specific cytokines, such as IL-12, IL-15, IL-18, and IL-21, and often referred as T cells redirected for universal cytokine-mediated killing or TRUCKS. IL-12 can improve $\mathrm{T}$-cell cytolytic activity, mitigate $\mathrm{T}$ regulatory cellmediated immunosuppression, and recruit and activate an innate immune cell response that can potentially avoid antigen-negative escape. As systemic administration of IL-12 was shown to cause severe side effects (146), constitutive or inducible expression of IL-12 has been integrated in CAR T cells (147-149). Expression of IL-15, either soluble or membrane-bound, improved survival and proliferation of CAR $\mathrm{T}$ cells without significant toxicity in vitro and in animal models (150-152). IL-18 is another cytokine included into TRUCKs and it was shown to improve CAR T-cell antitumor activity and increased NKG2D-positive NK cells tumor infiltration, while reducing the frequency of regulatory $\mathrm{T}$ cells and suppressive macrophages in the tumor micro-environment (153-155). Lastly, in a preclinical lymphoma model, IL-21 was shown to foster the generation of anti-tumor $\mathrm{T}$ cells with enhanced $\mathrm{Wnt} / \beta$-catenin pathway and stem-like properties, thus potentially leading to long-lived memory CAR T cells (156). Alternatively, some of the effects induced by cytokines can be obtained by including a cytokine signaling domain for IL-2R $\beta$ in the second-generation CAR construct (157).

Moreover, $\mathrm{T}$ cells can be redirected with additional domains to convert immunosuppressive signals into activating ones. For instance, dominant negative (DN) mutations of the TGF$\beta$ receptor in Epstein-Barr virus-specific $\mathrm{T}$ cells make them resistant to tumor-derived TGF- $\beta$ in a lymphoma model (158). Another strategy to overcome the immune suppressive signals from tumor microenvironment is the inclusion of the so-called "switch receptors." For example, the fusion of the extracellular domain of the IL-4 receptor with the intracellular one of the IL7 receptor results in the activation and proliferation of $\mathrm{T}$ cells in the presence of the normally inhibitory cytokine IL-4 $(159,160)$. Similarly, a PD-1/CD28 chimeric switch receptor can convert the PD-L1 immunosuppressive stimulus into a costimulatory signal (161). Armored CAR T cells can also be modified to express ligands for costimulatory molecules. For instance, the expression of CD40L on CAR T cells leads to the activation of endogenous antitumor immune response (162) while the expression of 4-1BB$\mathrm{L}$ increases the persistence of CD28-costimulated CART19 in BALL preclinical models (163). A clinical trial exploring armored CAR T cells in NHL and CLL is currently undergoing at MSKCC (NCT03085173) and preliminary results are promising (164). Additional effector functions can be obtained by the inclusion of chemokine receptors and ligands in armored CAR T cells. For example, IL-7 and CCL19 expression in CAR T cells was shown to improve their survival and activity in a solid tumor mouse model (165). Anti-CD30 CAR T cells expressing the chemokine receptor CCR4 showed better lymphoma infiltration and overall anti-tumor activity in preclinical models of Hodgkin lymphoma (166). Furthermore, anti-PD-L1 antibodies can be released by CAR T-cell within the tumor microenvironment, improving T-cell infiltration and functionality (167). An alternative and even more innovative approach has devised the generation of armored CAR T cells locally secreting PD-1-blocking scFv (168), thus avoiding potential toxicities associated with systemic checkpoint inhibition.

Furthermore, armored CAR $\mathrm{T}$ cells can secrete bispecific T-cell engagers or BiTEs. This technology allows targeting multiple tumor antigens together with the recruitment of tumorinfiltrating $\mathrm{T}$ cells. $\mathrm{T}$ cells that secrete BiTEs targeting tumor antigens such as EPHA2 (169), CD123 (170), and CD19 (171) are being developed.

\section{Modulating CAR T-Cell Regulation}

The field of engineering $\mathrm{T}$ cells, including gene editing and suicide genes strategies (172), is rapidly evolving and it will likely allow to increase the potency and safety of CAR T cells. T-cell exhaustion is an important factor limiting antiviral and antitumor responses in the setting of chronic antigen exposure $(173,174)$, and it also contribute to reduce CAR T-cell efficacy. The structure and the regulation of CAR expression on the surface of engineered $\mathrm{T}$ cells play a central role in predisposing CAR $\mathrm{T}$ cells to chronic activation and exhaustion (7). In particular, antigen-independent signaling has been found to drive early exhaustion of CAR T cells and to limit their antitumor efficacy in vivo $(7,175)$, and it can be influenced by the type and the position of the co-stimulatory domain, the spacer length, and/or the promoter or the vector used to express the CAR. Therefore, in order to prevent or delay CAR T-cell dysfunction, several efforts are being made to optimize the design and the expression of CAR constructs. Eyquem et al. reported on an innovative approach targeting a CAR coding sequence to the TCR locus and placing it under the control of endogenous regulatory elements (176). This method reduces tonic signaling, averts accelerated T-cell differentiation and exhaustion, and increases the therapeutic potency of engineered T cells. More recently, Viaud et al. demonstrated in a syngeneic lymphoma murine model that their "switchable" CAR T-cell platform, 
which can incorporate "rest" phases through cyclical dosing of the switch, was able to induce a robust central memory population and enhance CAR T-cell expansion and efficacy (177). These findings can have several clinical implications, since the engineering of more functional $\mathrm{T}$ cells might reduce the T-cell doses employed, therefore eliciting milder toxicities (172).

\section{EMERGING CAR T-CELL APPLICATIONS Chronic Lymphocytic Leukemia}

In recent years, CLL treatment paradigm has been revolutionized by B-cell receptor and BCL2 inhibitors (178). Nevertheless, relapses occur, especially in high-risk setting, such as patients with unfavorable genetic markers like TP53 mutations. CAR Tcell treatment could represent a viable option in case of treatment failure, or might directly compete with targeted therapiesespecially in patients with older age and unfavorable disease features, avoiding a long-term drug administration which can lead to toxicities (179), lack of compliance and ultimately cost problems (180).

Albeit CLL was one of the first diseases in which CAR T cells were used (15), experience is more limited compared to B-ALL or DLBCL. Nevertheless, safety and efficacy data are encouraging, especially in high risk patients (180).

The two FDA-approved anti-CD19 CAR T-cell constructs and JCAR017 are under investigation for R/R CLL $(14,50,181)$. Turtle and colleagues reported on 24 CLL patients, the vast majority (92\%) of whom had failed ibrutinib, treated with CD19$\mathrm{BBz}$ CAR $\mathrm{T}$ cells after receiving lymphodepleting chemotherapy. Four weeks after infusion, $\mathrm{CR}+\mathrm{PR}$ rate was $71 \%$. Twenty patients (83\%) developed CRS and eight developed NTX, with a fatal outcome in one patient. Fifty-eight percent of the patients who had deep sequencing of bone marrow samples after therapy reached MRD negativity. These data demonstrated that CAR $\mathrm{T}$ cells can be effective in CLL patients who failed targeted therapies, but longer follow-up is needed in order to evaluate the durability of such responses (52).

Thus far, remission rates obtained with CAR $\mathrm{T}$ cells in CLL are lower compared to B-ALL and DLBCL (14, 52, 96). Besides, responses appear to be weaker in the lymphnodes than in the bone marrow. Immune dysregulation typical of CLL may partly explain the lower efficacy of CAR T cells in these patients. Indeed, an impaired immune system (i.e., $\mathrm{CD} 8^{\text {pos }} \mathrm{T}$ cells with low proliferative and cytotoxic capacities, and/or less expansion of "naïve" $\mathrm{CD} 4^{\text {pos }} \mathrm{T}$ cells) can lead to decreasing CAR T-cell activation after transduction $(182,183)$. These intrinsic characteristics of CLL milieu are usually present at the time of diagnosis but are also favored by previous lines of treatment, particularly by fludarabine. These data could support the development of allogeneic CAR T cells from healthy donors, in whom the activity and cytotoxicity of $\mathrm{T}$ cells are not modified by the tumor clone (see section Alternative Sources) or the association with immunomodulatory agents, as discussed supra. Recent results of a pilot study evaluating CD19 CAR T cells concomitantly to ibrutinib in CLL $(n=19)$ showed a good tolerability, with robust CAR T-cell expansion and decreased CRS severity as compared to CLL patients treated with CAR T cells without ibrutinib, and similar response rates and long-term outcomes (184).

Alternative antigenic targets other than CD19 are under investigation in CLL, such as clonal light chain (kappa or lambda), CD23, the receptor of the invariant fragment of IgM $(\mathrm{Fc} \gamma \mathrm{R})$, and ROR1 $(102,107,185,186)$. Selected clinical trial results in CLL are summarized in Table 2.

\section{Multiple Myeloma}

Recently, clinical and basic research on CAR T-cell treatment for MM has started to yield encouraging results and, among the MMspecific targets current under investigation, B-cell maturation antigen (BCMA) seems to be the most promising one (187). Indeed, two phase I clinical trials, conducted, respectively, at the NIH (NCT02215967) (188) and UPenn (NCT02546167) (189), showed remarkable results in preliminary reports.

Data about a third phase I multicenter trial (NCT02658929) exploring the second-generation CAR bb2121, composed of antiBCMA scFv and a 4-1BB costimulatory domain, were recently published (190). The first 33 highly pretreated patients who received a bb2121 infusion showed an ORR of $85 \%$, with a CR rate of $45 \%$. A dose-dependent effect on the frequency and duration of response was observed: VGPR or better were observed only with doses $\geq 150 \times 10^{6}$ CAR T cells. Median follow-up was 11.3 months and median duration of response was 10.9 months. CAR T-cell expansion was associated with response, and CAR T cells persisted up to 1 year after the infusion. Median PFS was 11.8 months, comparing favorably with other salvage therapies for a similar population $(191,192)$. CRS and NTX were reported in 76 and $42 \%$ of the patients, respectively, and were mostly mild. Phase II and III multicenter studies evaluating the efficacy and safety of bb2121 in subjects with R/R MM are currently ongoing in the US and in Europe (NCT03361748 and NCT03601078).

Results of another phase I trial in R/R MM patients employing LCAR-B38M, a bispecific CAR T-cell product that binds BCMA at two separate antigenic epitopes, were recently reported (193). After lymphodepletion based on cyclophosphamide, LCARB38M CAR T cells were administered in three separate infusions. At data cutoff, 57 patients received the product. CRS occurred in $90 \%$ of patients, $7 \%$ being grade $\geq 3$ and one patient reported severe NTX. The ORR was $88 \%$, including $68 \%$ of CR and MRD negativity was achieved by $63 \%$ of the patients. After a median follow-up of 8 months, median PFS was 15 months.

Although associated with high ORR, the main problem of anti-BCMA CAR $T$ cells is the relatively short durability of responses, possibly due to the loss or down regulation of BCMA expression on MM cells and CAR T-cell limited persistence or functional exhaustion (194).

In addition to BCMA, alternative target antigens expressed on MM cells surface and compound CART cells expressing two (or more) different CARs are under investigation. Yan et al. explored the activity and safety of a combination of humanized anti-CD19 and murine anti-BCMA CAR T cells in patients with R/R MM (195). Twenty-one patients were infused and, after a median follow-up of almost 6 months, 95\% of patients had an objective response, including nine stringent CR. The 
most common adverse event was CRS (90\% of the patients), including $14 \%$ grade $3 / 4$ cases. Ongoing studies are investigating several other potential targets on MM plasma cell surface (196), including CD44v6 (197), Lewis Y (198), NKG2D ligands (199), CD229 (200), and integrin $\beta 7$ (201). Selected clinical trial results in MM are summarized in Table 3.

\section{Perspectives in Other Settings}

In $\mathrm{R} / \mathrm{R}$ Hodgkin lymphoma, CD30-directed CAR T-cell therapy showed a manageable safety profile and significant activity in phase I clinical trials, employing either CD30-BBz (202) or CD30-28z CAR T-cell products (203), especially after lymphodepleting chemotherapy was introduced (204). Nevertheless, the number of patients treated so far is small. Furthermore, CD30-directed CAR T cells are being evaluated in CD30-positive anaplastic large cell lymphoma, with encouraging results $(202,203)$.

In T-cell neoplasms, the development of CAR T cells been limited by the difficulty of targeting malignant cells without killing the very effector cells (fratricide) (205). Thus, several efforts have been made to find tumor-specific antigens (e.g., CD1a), which would prevent prolonged T-cell aplasia as well (206-208). Besides, fratricide killing could be avoided by knocking-out the target gene on effector cells using gene editing approaches (e.g., TALEN or CRISPR/Cas9), with some preclinical experience on CD7-knockout anti-CD7 CAR T cell already published $(206,209)$. Finally, CAR NK and allogeneic CAR T cells are being tested, with the advantage of avoiding a potential contamination of the product with malignant T cells and, for NK, also fratricidal killing (206) (see section Alternative Sources).

The development of CAR T cells for advanced solid tumors and relapsed/refractory AML, still associated with unfavorable prognosis despite recent therapeutic developments (210), has been limited by the absence of a suitable tumor-specific antigen $(211,212)$ and severe and toxicities due to on-target off-tumor effects occurred in some trials (213-217). Thus, investigators are trying to find more suitable targets $(218,219)$ and exploring strategies to promptly induce CAR T-cell exhaustion only when needed (220), such as mRNA electroporation $(221,222)$ and inducible suicide genes (223). CARs co-targeting two or three antigens are also being developed, aiming at preventing possible off-tumor side effects but also at avoiding antigen escape risk (115, 224-229). In solid malignancies, tumor microenvironment represents an unique obstacle which can significantly hamper CAR T-cell efficacy (230). Thus, innovative strategies such as CAR T-cell local delivery (231-234) and PD-1/PD-L1 axis block are being explored $(120,121,235,236)$.

A detailed description of the limited clinical results available so far has been recently reviewed elsewhere $(212,237)$.

\section{ALTERNATIVE SOURCES}

\section{Allogeneic CAR T Cells}

Because of manufacturing issues, especially in heavily pre-treated patients, CAR T-cell production sometimes fails or requires too long; thus, universal allogeneic anti-CD19 CAR T-cell products obtained from healthy donors (off-the-shelf products) could represent a readily available solution. However, allogeneic T cells have very high alloreactive potential, because of TCR natural reaction against non-autologous tissues. Recently, thanks to gene editing technology, researchers succeeded in preventing the expression of endogenous TCR knocking down the TRAC gene (i.e., the gene codifying $\alpha$ chain of TCR), in order to minimize graft-versus-host disease (GVHD) risk in non-HLA matched recipients. As a matter of fact, TRAC loci can be disrupted using electrotransfer of mRNA codifying various nucleases (238-240), such as zinc finger nucleases (ZFN) (241), transcription activatorlike effector nucleases (TALEN), megaTAL nucleases (242-244), and CRISPR/Cas9 systems (245).

UCART19 (a CD19-BBz product) is modified to lack both CD52 expression and the endogenous TRAC locus, and to include a RQR8 marker-suicide gene as "safety switch." In this way, these allogeneic CAR T cells become resistant to anti-CD52 monoclonal antibody alemtuzumab, used for lymphodepletion along with cyclophosphamide and fludarabine to increase CAR T-cell persistence, and precautionary targeted elimination through anti-CD20 monoclonal antibody rituximab becomes possible. A phase I pediatric trial (PALL, NCT02808442) for highrisk R/R CD19-positive B-ALL and a phase I dose-escalation adult trial (CALM, NCT02746952) for patients with R/R BALL are underway. Preliminary data were presented at 2018 American Society of Hematology meeting (43). A total of 20 patients received at least one UCART19 infusion, 13 in CALM and 7 in PALL trial. After UCART19 infusion, $88 \%$ of evaluable patients (14/16) achieved CR or CRi, and $86 \%(12 / 14)$ of them reached MRD negativity. Globally, 11 patients underwent alloHSCT. Preliminary data suggested that anti-leukemic activity was linked to CAR T-cell expansion. Severe CRS was reported in $15 \%$ of the patients and no severe NTX occurred. Grade 1 acute GVHD was reported in two patients.

In $\mathrm{MM}$, allogeneic anti-BCMA CAR $\mathrm{T}$ cells induced sustained antitumor responses in mouse models and, importantly, maintained their phenotype and potency after scale-up manufacturing, standing promisingly for clinical evaluation (246).

Despite the reduced GVHD risk of TCR-negative off-the-shelf CAR T cells, these cells are exposed to killing by the patient's own mismatched $\mathrm{T}$ cells, leading to rejection and subsequently short-lasting response. Therefore, several attempts are under investigation to protect allogeneic CAR $\mathrm{T}$ cells from rejection, such as the use of ZFN gene-editing technology to eliminate HLA molecule expression from CAR T cells (247). Moreover, investigators are also trying to prevent $\mathrm{NK}$ activation, a possible cause of CAR T-cell rejection due to "missing self" recognition, enforcing expression of non-classical HLA molecules (i.e., HLAE and HLA-G) (247-250).

An alternative approach - borrowed from regenerative medicine - is the generation of tumor-targeting $\mathrm{T}$ cells from induced pluripotent stem cells (iPSC), allowing to exploit the unlimited proliferative capabilities of iPSC together with the CAR-directed antigen specificity. Themeli et al. generated CD19-CAR-expressing $\mathrm{T}$ cell-derived iPSC with an effector 
TABLE 3 | Selected clinical trials of CAR T cells in multiple myeloma.

\begin{tabular}{|c|c|c|c|c|c|c|c|c|c|c|c|c|c|}
\hline Setting & Target & Product & $\begin{array}{l}\text { Costimul. } \\
\text { domain }\end{array}$ & Generation & Vector & $\begin{array}{l}\text { Population } \\
\text { infused }\end{array}$ & Response & $\begin{array}{l}\text { Durable } \\
\text { remission rate }\end{array}$ & $\begin{array}{l}\text { CRS } \\
\text { (gr.3/4) }\end{array}$ & $\begin{array}{l}\text { NTX } \\
\text { (gr.3/4) }\end{array}$ & Institute/Company & Clinical trial & References \\
\hline \multirow[t]{6}{*}{ MM } & $\mathrm{BCMA}$ & BCMA.CAR & CD28 & Second (2nd) & Retroviral & $16, \mathrm{R} / \mathrm{R} \mathrm{MM}$ & $\begin{array}{l}\text { ORR } 81 \% \\
\geq \text { VGPR 63\% }\end{array}$ & Unknown & $38 \% \S$ & $6 \%\urcorner$ & $\mathrm{NIH}$ & $\begin{array}{l}\text { NCT02215967 } \\
\text { Phase I }\end{array}$ & (188) \\
\hline & & CART-BCMA & $4-1 \mathrm{BB}$ & Second $\left(2^{\text {nd }}\right)$ & Lentiviral & 25, R/R MM & ORR $48 \%$ & $\begin{array}{l}\text { Median DOR } \\
\approx 4 \mathrm{mo}\end{array}$ & $32 \% ¥$ & $12 \%^{*}$ & UPenn/Novartis & $\begin{array}{l}\text { NCT02546167 } \\
\text { Single-center, } \\
\text { phase I }\end{array}$ & (189) \\
\hline & & bb2121 & 4-1BB & Second (2nd) & Lentiviral & 33, R/R MM & $\begin{array}{l}\text { ORR 85\% } \\
\text { CR } 45 \%\end{array}$ & $\begin{array}{l}\text { Median DOR } \\
10.9 \mathrm{mo}\end{array}$ & $6 \% \S$ & $3 \%^{ \pm}$ & $\begin{array}{l}\mathrm{NIH} / \text { Bluebird Bio, } \\
\text { Celgene }\end{array}$ & $\begin{array}{l}\text { NCT02658929 } \\
\text { Multicenter } \\
\text { phase I }\end{array}$ & (190) \\
\hline & & LCAR-B38M & None & First (1st) & Lentiviral & 57, R/R MM & $\begin{array}{l}\text { ORR 88\% } \\
\text { CR 68\% }\end{array}$ & $\begin{array}{l}\text { Median DOR } \\
14 \mathrm{mo}\end{array}$ & $7 \% \S$ & $2 \%^{ \pm}$ & $\begin{array}{l}\text { Nanjing Legend } \\
\text { Biotech }\end{array}$ & $\begin{array}{l}\text { LEGEND-2 } \\
\text { NCT03090659 } \\
\text { Multicenter } \\
\text { phase I/II }\end{array}$ & (193) \\
\hline & $k-\lg L C$ & к. CAR & CD28 & Second (2nd) & Retroviral & 7, R/R MM & $\geq P R 57 \%$ & Unknown & $0 \%{ }^{*}$ & $0 \% *$ & $\mathrm{BCM}$ & $\begin{array}{l}\text { CHARKALL } \\
\text { NCT00881920 } \\
\text { Phase I }\end{array}$ & (102) \\
\hline & NKG2DL & CM-CS1T & $\begin{array}{l}\text { CD3̧ plus } \\
\text { DAP10 }\end{array}$ & Second (2nd) & Retroviral & 5, R/R MM & - & - & - & - & DFCl/Celyad & $\begin{array}{l}\text { NCT02203825 } \\
\text { in vitro } \\
\text { Phase I }\end{array}$ & (199) \\
\hline
\end{tabular}

$¥$ ¥, Penn/CHOP grading scale; §, NCl 2014 consensus grading scale modified by Lee DW et al. (45); ", CTCAE v4.0; ᄀ, CTCAE v4.02; 土, CTCAE v4.03.

$M M$, multiple myeloma; $R / R$, relapse/refractory; ORR, overall response rate; $C R$, complete remission; $P R$, partial response; VGPR, very good partial response; SD, stable disease; wk, weeks; EFS, event-free survival: DOR, duration of response; PFS, progression-free survival; CRS, cytokine release syndrome; NTX, neurotoxicity; UPenn, University of Pennsylvania Hospital; DFCl, Dana-Faber Cancer Institute; NIH, National Institutes of Health; BCM, Baylor College of Medicine. 
memory phenotype, which were effective in killing CD19positive lymphoma cells (251). Among the products currently under development for clinical application, FT819, an off-theshelf iPSC product, is engineered to express a CD19-CAR together with the antibody-engaging CD16 Fc receptor (allowing dual-targeting), and to eliminate the TCR surface expression. FT819 was evaluated in the pre-clinical setting, resulting effective in targeting tumor cells both in vitro and in vivo in a mouse model of ALL (252). However, before moving to human studies, the risk of transferring undifferentiated iPSC with tumorigenic potential and the issue of host rejection need to be carefully addressed.

\section{CAR NK Cells}

Another potential source of CAR carrier for off-the-shelf products is represented by NK cells. NK cells, which constitute approximately $10 \%$ of circulating lymphocytes, are efficient immune effector cells with a recognized role in the control of neoplastic proliferation (253). The interest toward these cells in this setting depends on their specific characteristics. In addition to the CAR-specific target recognition, transduced NK cells retain the ability to recognize neoplastic cells through their innate receptors, thus reducing the risk of tumor escape (254). Since NK cells do not require HLA matching for target recognition, allogeneic NK cells do not cause GVHD. Also, the limited lifespan of NK cells reduces the risk of long term side effects.

Allogeneic NK cells can be derived from donor peripheral blood, bone marrow, or even from cord blood. Indeed, cord blood represents an optimal source, since NK cells can be readily available and can usually be collected in clinically relevant doses for adoptive immunotherapy (255). NK cells engineered to express a CD19-directed CAR, to ectopically produce IL15 as a support for survival and proliferation, and to express a suicide gene (i.e., inducible caspase-9) showed killing ability in vitro and in vivo in a mouse model (256). The preliminary results of a trial exploring the safety and efficacy of CD19-28z2A-iCasp9-IL15 transduced cord blood NK cells in patients with relapsed or refractory CD19-positive B-lymphoid malignancies (NCT03056339) have been recently published by Rezvani group. After lymphodepleting chemotherapy, 11 patients received a single infusion of CAR-NK. Eight of the 11 treated patients rapidly responded (within 30 days), 7 of whom achieving CR and no major side effect was recorded, including CRS, NTX, or GVHD (257).

Cell lines represent an alternative NK cell source, and among them NK-92 is the most widely used. NK-92 was established from a patient with NK-cell lymphoma, and is characterized by an activated NK-cell phenotype and a strong cytotoxic activity which, however, may not be sufficient to kill clonal cells of lymphoid origin $(258,259)$. CD19-CAR construct can be effectively expressed on NK-92 cells, conferring cytolytic capability toward previously resistant CD19-positive neoplastic cells in vitro and in mouse models (260-262). However, before in vivo application, cells need to be irradiated to avoid tumor engraftment, possibly negatively impacting on their efficiency.

A phase I/II trial evaluating PCAR-119 (NK-92 cell line engineered to express a CD19-TCRzeta-CD28-4-1BB CAR) in patients with CD19-positive lymphoproliferative diseases is currently open in China (NCT02892695), but results are not available yet. The result of the first-in-man clinical trial of CAR NK-92 cells have been reported in the setting of AML, where three patients were treated with a CD33 CAR NK-92, demonstrating the feasibility of the procedure (263).

\section{INTEGRATION OF CAR T CELLS INTO CLINICAL ROUTINE}

\section{FACT Standards for Immune Effector Cells}

Since 1966, the Foundation for the Accreditation of Cellular Therapy (FACT) has promoted quality practice in HSCT. More recently, FACT has broadened its objectives to also include standards in the nascent field of cellular therapies. In this context, FACT recently published the first edition of the Standards for Immune Effector Cells (IEC). These Standards apply to immune effector cells used to modulate an immune response for therapeutic intent, such as dendritic cells, natural killer cells, $\mathrm{T}$, and B cells. This includes, but is not limited to, CAR T-cell therapy and vaccines (264).

Requirements for programs that administer immune effector cells in a center that is not already FACT-accredited are fully contained in the FACT IEC Standards. When IEC are administered in a FACT-JACIE accredited stem cell transplantation unit, the program must fully comply with the new 7th edition of FACT-JACIE Hematopoietic Cell Therapy Standards (265).

\section{Treating Site Preparation and Logistics}

Each institution that initiates a CAR T-cell therapy program will face both clinical and administrative challenges before offering this new therapy to patients. This process involves complex logistics that cover the collection of cells at the apheresis center, shipping them to the manufacturer for production, coordinating receipt of the product, and defining an ideal workflow for CAR T-cell administration and patient management (266-269).

Hospitals need to develop a CAR T-cell consultation service to facilitate patient selection and treatment. Ideally, this service should consist of a multidisciplinary team that includes physicians, nurses, and social workers with expertise in cellular therapies, and an effective administrative infrastructure that ensures the execution of the workflow. There should be open communication between the center's and manufacturing site's staffs regarding any questions related to the timing of delivery and product quality. This multidisciplinary team, including physicians with expertise in CAR T cells and different medical specialists, should have regular meetings to review each patient's treatment course, and to develop institutional guidelines that include algorithms for the management of expected adverse events, such as CRS and NTX, and recommendations for the clinical staff of different departments (e.g., pharmacy, emergency department, neurology and intensive care unit). This is in accordance with Risk Evaluation and Mitigation Strategy (REMS) programs to reduce the potential risks of CAR T-cell agents, which require authorized centers to comply with specific guidelines, including the training of providers who prescribe, 
dispense, and administer CAR T cells. REMS programs also mandate patients and caregivers' education about toxicities, including a REMS wallet card given to each patient which reports the key symptoms possibly related to CAR T-cell therapy and the contacts of the referent physicians (270).

In many centers in the U.S., transplant programs have assumed this responsibility as they have clinical expertise in the diseases currently being treated with CAR T cells, and they are also well-versed in the logistics and regulatory aspects of delivering cellular therapies. However, some centers have developed other models, including self-standing immune effector cells services, or decided to deliver CAR T cells in diseasespecific services.

Finally, community oncologists play a critical role, recognizing potentially eligible patients and following them after CAR T-cell treatment has been administered. Thus, to ensure optimal long-term outcomes for patients, it becomes essential to establish a prolonged communication between the reference center and the local oncologist, who must be familiar with common toxicities and their monitoring and management (271).

\section{CIBMTR Guidelines for Cellular Therapies}

Data registries of HSCT recipients across Europe and United States have been essential to evaluate long-term follow-up results in this field. During the summer of 2016, the United States based Center for International Blood and Marrow Transplant Research (CIBMTR) launched the new Cellular Therapy Registry forms. These forms, based on the design of the transplant forms, aim to collect information on all cellular therapies including CAR $\mathrm{T}$ cells. The goal of the CIBMTR Cellular Immunotherapy Data Resource (CIDR) is to centralize cellular therapy data collection and reporting requirements such as the United States FDA follow-up obligation for genetically modified cells.

Additionally, in February 2018, the European Medicines Agency (EMA) workshop, including members from the European Society for Blood and Marrow Transplant (EBMT) and from the CIBMTR, reported their immediate priorities on patient data registries on CAR T-cell therapy (272). Specifically, they aimed to harmonize data element definitions across registries, to establish measures that ensure data are collected systematically with appropriate verification and quality assurances, to ensure arrangements are in place to permit data sharing, and to improve communications between registry holders, regulators and marketing authorization holders and applicants. The report also included recommendations to facilitate and improve registry data use including the systematic collection of a set of core commonly-defined data elements (273).

\section{DISCUSSION}

The advent of CAR T-cell treatment is revolutionizing established oncology paradigms, especially - to date - in B-cell malignancies. CAR T cells have already entered the treatment armamentarium for B-ALL and aggressive B-NHL, and the first presented real world data are reassuring and globally confirmed results of clinical trials (274-276), showing efficacy even beyond current indications $(37,277)$. The preclinical and clinical research field is extremely active, and we can anticipate an increase in treatment indications and available products in the near future. Indeed, the exciting results of ZUMA-2 trial in R/R MCL (29) open new possibilities in this difficult lymphoma subtype, and tisacel (ELARA trial, NCT03568461) and axi-cel (ZUMA-5 trial, NCT03105336) are being evaluated in R/R indolent lymphomas as well. Furthermore, the promising data on CAR NK and allergenic CAR $\mathrm{T}$ cells are opening the road to off-the-shelf products $(43,257)$.

CAR T-cell results are still hard to compare to those obtained with conventional treatment options, especially for the oldest trials lacking of data by intention-to-treat and considering the heterogeneity of treated patients [e.g., B-ALL patients with MRD positivity and in full blown relapse (33) included in the same trials]. Long-term outcomes are of extreme importance to this purpose and data need to be carefully collected. Globally, updated reports of the largest clinical trials are quite positive, since the persistence of responses observed in B-ALL and B-NHL seems confirmed in the majority of the cases, but follow-up duration remains relatively limited $(25,26,28)$.

Importantly, several practical issues need to be considered in order to offer this treatment to all patients who may need it and to integrate CAR T cells in the evolving treatment paradigm of B-cell malignancies.

In the setting of B-ALL, a recent expert opinion from the EBMT and the ASTCT (278) has addressed the possible drawbacks of new treatment options, such as blinatumomab and inotuzumab ozogamicin, and their place in the context of novel cellular therapies. For instance, blinatumomab, which represents an important option for relapsed and MRD positive patients, should be avoided as a bridging therapy before CAR T-cell infusion to minimize the risk of antigen loss $(278,279)$, although some conflicting data on this issue have been reported (31). The role of allogeneic HSCT after CAR T-cell therapy is being actively debated as well, since some patients (i.e., those with prolonged CAR T-cell persistence and confirmed MRD negative remission) might not need it. The OBERON trial (NCT03628053), a randomized open label multicenter phase III study comparing tisagenlecleucel vs. blinatumomab or inotuzumab in R/R ALL patients, will hopefully better clarify the role of each agent in the treatment paradigm of B-ALL.

In aggressive $\mathrm{B}-\mathrm{NHL}$, two CAR T-cell products are now commercially available, and a third one in advanced stage of development (280), thus the question of which one might be preferred will soon be posed. Given the remote possibility of head-to-head randomized clinical trials and the difficulty of driving definitive conclusions from the indirect comparison of the available studies, the issue will likely remain open, with each center experience playing an important role. Furthermore, the role of allo-HSCT in this disease group is probably going to change. Given the relatively limited non-relapse mortality and the fairly good long-term results of CAR T-cell therapy in heavily pretreated R/R B-NHL patients, some authors are now suggesting to employ it earlier in the course of the disease, reserving alloHSCT for patients who relapse after or who are refractory to 
CAR T cells (281). Besides, ongoing clinical trials [i.e., BELINDA (NCT03570892), ZUMA-7 (NCT03391466), and TRANSFORM (NCT03575351)] are challenging the place of autologous HSCT, which is being directly tested against CAR T cells, or exploring the use of CAR T cells following autologous HSCT in poor-risk patients (282).

Even in the presence of available commercial products, the enrollment in clinical trials remains essential, both to test newer and hopefully better constructs and to clarify their position in the treatment landscape of each disease. Early referral to centers providing these therapies thus becomes of paramount importance.

Another relevant issue is the affordability of these treatments, especially in the context of public health care systems. As a matter of fact, the total cost for axicabtagene ciloleucel or tisagenlecleucel treatment is close to 1 million dollars per patient, considering the price of the product and all the expenses related to the supportive measures needed (283). Several analyses have been recently presented to address the issue and, albeit quite positive in terms of cost-effectiveness, their conclusions will be confirmed only when mature data on the durability of remission, long-term survival and rate of alloHSCT will be available (283-287). As CAR T-cell therapy becomes available for more indications, the price of the products will hopefully start to be lowered, improving cost-effectiveness and allowing more patients to get access to these treatments. In order to reduce costs, point-of-care production systems, which employ fully automated

\section{REFERENCES}

1. June $\mathrm{CH}$, Sadelain M. Chimeric antigen receptor therapy. $N$ Engl J Med. (2018) 379:64-73. doi: 10.1056/NEJMra1706169

2. Bird RE, Hardman KD, Jacobson JW, Johnson S, Kaufman BM, Lee SM, et al. Single-chain antigen-binding proteins. Science. (1988) 242:4236. doi: 10.1126/science.3140379

3. Gross G, Waks T, Eshhar Z. Expression of immunoglobulin-T-cell receptor chimeric molecules as functional receptors with antibody-type specificity. Proc Natl Acad Sci USA. (1989) 86:10024-8. doi: 10.1073/pnas.86.24.10024

4. Huston JS, Levinson D, Mudgett-Hunter M, Tai MS, Novotny J, Margolies $\mathrm{MN}$, et al. Protein engineering of antibody binding sites: recovery of specific activity in an anti-digoxin single-chain Fv analogue produced in Escherichia coli. Proc Natl Acad Sci USA. (1988) 85:587983. doi: 10.1073/pnas.85.16.5879

5. Letourneur F, Klausner RD. T-cell and basophil activation through the cytoplasmic tail of T-cell-receptor zeta family proteins. Proc Natl Acad Sci USA. (1991) 88:8905-9. doi: 10.1073/pnas.88.20.8905

6. Jensen MC, Popplewell L, Cooper LJ, DiGiusto D, Kalos M, Ostberg JR, et al. Antitransgene rejection responses contribute to attenuated persistence of adoptively transferred CD20/CD19-specific chimeric antigen receptor redirected T cells in humans. Biol Blood Marrow Transplant. (2010) 16:124556. doi: 10.1016/j.bbmt.2010.03.014

7. Long AH, Haso WM, Shern JF, Wanhainen KM, Murgai M, Ingaramo $\mathrm{M}$, et al. 4-1BB costimulation ameliorates $\mathrm{T}$ cell exhaustion induced by tonic signaling of chimeric antigen receptors. Nat Med. (2015) 21:58190. doi: $10.1038 / \mathrm{nm} .3838$

8. Salter AI, Ivey RG, Kennedy JJ, Voillet V, Rajan A, Alderman EJ, et al. Phosphoproteomic analysis of chimeric antigen receptor signaling reveals kinetic and quantitative differences that affect cell function. Sci Signal. (2018) 11:aat6753. doi: 10.1126/scisignal.aat6753 devices to manufacture CAR T cells, are being tested, possibly reducing the production time as well (288).

After a long road started more than 20 years ago, CAR T-cell therapies have become commercially available. The better understanding of CAR T-cell biology will help to develop strategies to improve their efficacy and safety. New applications in several hematological malignancies and solid tumors are also emerging, but need to be validated by the results of ongoing studies. Nevertheless, translating their application from the small scale of early-phase clinical trials to the large scale of clinical practice will require considerable scientific, logistic, and economic efforts.

\section{AUTHOR CONTRIBUTIONS}

MCe, MR, M-AP, CV, GP, and BB designed and conceived the review. All the authors collected data. $\mathrm{MCe}, \mathrm{CV}$, and $\mathrm{DF}$ assembled data. MCe, MR, M-AP, CV, DF, GP, and BB wrote the initial draft of the manuscript. All authors revised and approved the final submitted version of the manuscript.

\section{FUNDING}

CV was a recipient of a Fondazione Pezcoller - Ferruccio ed Elena Bernardi fellowship, from Pezcoller Foundation in collaboration with SIC (Società Italiana di Cancerologia).

9. Eshhar Z, Waks T, Gross G, Schindler DG. Specific activation and targeting of cytotoxic lymphocytes through chimeric single chains consisting of antibody-binding domains and the gamma or zeta subunits of the immunoglobulin and T-cell receptors. Proc Natl Acad Sci USA. (1993) 90:720-4. doi: 10.1073/pnas.90.2.720

10. Goverman J, Gomez SM, Segesman KD, Hunkapiller T, Laug WE, Hood L. Chimeric immunoglobulin-T cell receptor proteins form functional receptors: implications for $\mathrm{T}$ cell receptor complex formation and activation. Cell. (1990) 60:929-39. doi: 10.1016/0092-8674(90)90341-B

11. Cooper LJ, Topp MS, Serrano LM, Gonzalez S, Chang WC, Naranjo A, et al. T-cell clones can be rendered specific for CD19: toward the selective augmentation of the graft-versus-B-lineage leukemia effect. Blood. (2003) 101:1637-44. doi: 10.1182/blood-2002-07-1989

12. Kowolik CM, Topp MS, Gonzalez S, Pfeiffer T, Olivares S, Gonzalez $\mathrm{N}$, et al. CD28 costimulation provided through a CD19-specific chimeric antigen receptor enhances in vivo persistence and antitumor efficacy of adoptively transferred $\mathrm{T}$ cells. Cancer Res. (2006) 66:10995-104. doi: 10.1158/0008-5472.CAN-06-0160

13. Kochenderfer JN, Wilson WH, Janik JE, Dudley ME, StetlerStevenson M, Feldman SA, et al. Eradication of B-lineage cells and regression of lymphoma in a patient treated with autologous $\mathrm{T}$ cells genetically engineered to recognize CD19. Blood. (2010) 116:4099-102. doi: 10.1182/blood-2010-04-281931

14. Porter DL, Hwang WT, Frey NV, Lacey SF, Shaw PA, Loren AW, et al. Chimeric antigen receptor $\mathrm{T}$ cells persist and induce sustained remissions in relapsed refractory chronic lymphocytic leukemia. Sci Transl Med. (2015) 7:303ra139. doi: 10.1126/scitranslmed. aac5415

15. Porter DL, Levine BL, Kalos M, Bagg A, June CH. Chimeric antigen receptormodified T cells in chronic lymphoid leukemia. N Engl J Med. (2011) 365:725-33. doi: 10.1056/NEJMoa1103849 
16. Maude SL, Frey N, Shaw PA, Aplenc R, Barrett DM, Bunin NJ, et al. Chimeric antigen receptor T cells for sustained remissions in leukemia. $\mathrm{N}$ Engl J Med. (2014) 371:1507-17. doi: 10.1056/NEJMoa1407222

17. Brentjens RJ, Davila ML, Riviere I, Park J, Wang X, Cowell LG, et al. CD19-targeted $\mathrm{T}$ cells rapidly induce molecular remissions in adults with chemotherapy-refractory acute lymphoblastic leukemia. Sci Transl Med. (2013) 5:177ra38. doi: 10.1126/scitranslmed.3005930

18. Kochenderfer JN, Dudley ME, Kassim SH, Somerville RP, Carpenter RO, Stetler-Stevenson M, et al. Chemotherapy-refractory diffuse large B-cell lymphoma and indolent B-cell malignancies can be effectively treated with autologous T cells expressing an anti-CD19 chimeric antigen receptor. J Clin Oncol. (2015) 33:540-9. doi: 10.1200/JCO.2014.56.2025

19. Kochenderfer JN, Somerville RPT, Lu T, Yang JC, Sherry RM, Feldman SA, et al. Long-duration complete remissions of diffuse large B cell lymphoma after anti-CD19 chimeric antigen receptor T cell therapy. Mol. Ther. (2017) 25:2245-53. doi: 10.1016/j.ymthe.2017.07.004

20. Grupp SA, Kalos M, Barrett D, Aplenc R, Porter DL, Rheingold SR, et al. Chimeric antigen receptor-modified T cells for acute lymphoid leukemia. $N$ Engl J Med. (2013) 368:1509-18. doi: 10.1056/NEJMoa1215134

21. Maude SL, Laetsch TW, Buechner J, Rives S, Boyer M, Bittencourt H, et al. Tisagenlecleucel in children and young adults with B-Cell lymphoblastic leukemia. N Engl J Med. (2018) 378:439-48. doi: 10.1056/NEJMoa1709866

22. Neelapu SS, Locke FL, Bartlett NL, Lekakis LJ, Miklos DB, Jacobson CA, et al. Axicabtagene ciloleucel CAR T-cell therapy in refractory large B-cell lymphoma. N Engl J Med. (2017) 377:2531-44.

23. Locke FL, Neelapu SS, Bartlett NL, Siddiqi T, Chavez JC, Hosing CM, et al. Phase 1 results of ZUMA-1: a multicenter study of KTE-C19 anti-CD19 CAR T cell therapy in refractory aggressive lymphoma. Mol. Ther. (2017) 25:285-95. doi: 10.1016/j.ymthe.2016.10.020

24. Bouchkouj N, Kasamon YL, de Claro RA, George B, Lin X, Lee $S$, et al. FDA approval summary: axicabtagene ciloleucel for relapsed or refractory large B-cell Lymphoma. Clin. Can. Res. (2019) 25:17028. doi: 10.1158/1078-0432.CCR-18-2743

25. Locke FL, Ghobadi A, Jacobson CA, Miklos DB, Lekakis LJ, Oluwole OO, et al. Long-term safety and activity of axicabtagene ciloleucel in refractory large B-cell lymphoma (ZUMA-1): a single-arm, multicentre, phase 1-2 trial. Lancet Oncol. (2019) 20:31-42. doi: 10.1016/S1470-2045(18)30864-7

26. Schuster SJ, Bishop MR, Tam CS, Waller EK, Borchmann P, McGuirk JP, et al. Tisagenlecleucel in adult relapsed or refractory diffuse large B-Cell lymphoma. N Engl J Med. (2019) 380:45-56. doi: 10.1056/NEJMoa1804980

27. Poh A. JCAR015 in ALL: a root-cause investigation. Cancer Discov. (2018) 8:4-5. doi: 10.1158/2159-8290.CD-NB2017-169

28. Abramson JS, Palomba ML, Gordon LI, Lunning MA, Wang ML, Arnason JE, et al. Pivotal safety and efficacy results from transcend NHL 001, a multicenter phase 1 study of lisocabtagene maraleucel (liso-cel) in Relapsed/Refractory (R/R) large B cell Lymphomas. Blood. (2019) 134(Suppl. 1):241. doi: 10.1182/blood-2019-127508

29. Wang M, Munoz J, Goy A, Locke FL, Jacobson CA, Hill BT, et al. KTE-X19 CAR T-cell therapy in relapsed or refractory mantle-cell lymphoma. $N$ Engl J Med. (2020) 382:1331-42. doi: 10.1056/NEJMoa1914347

30. Shah BD, Bishop MR, Oluwole OO, Logan A, Baer MR, Donnellan WB, et al. End of phase I results of ZUMA-3, a phase 1/2 study of KTE-X19, anti-CD19 chimeric antigen receptor (CAR) T cell therapy, in adult patients (pts) with relapsed/refractory (R/R) acute lymphoblastic leukemia (ALL). J Clin Oncol. (2019) 37(Suppl. 15):7006. doi: 10.1200/JCO.2019.37.15_suppl.7006

31. Shah BD, Oluwole OO, Baer MR, Bishop MR, Holmes HE, Schiller GJ, et al. Outcomes of patients (pts) treated with prior blinatumomab (Blin) in ZUMA-3: A study of KTE-C19, an anti-CD19 chimeric antigen receptor $(\mathrm{CAR}) \mathrm{t}$ cell therapy, in adult pts with relapsed/refractory acute lymphoblastic leukemia (R/R ALL). J Clin Oncol. (2018) 36(Suppl. 15):7006. doi: 10.1200/JCO.2018.36.15_suppl.7006

32. Wayne AS, Huynh V, Hijiya N, Rouce R, Brown PA, Krueger J, et al. Phase 1 results of zuma-4: kte-x19, an anti-cd19 chimeric antigen receptor $t$ cell therapy, in pediatric and adolescent patients with relapsed/refractory b cell acute lymphoblastic leukemia: ps962. HemaSphere. (2019) 3:433. doi: 10.1097/01.HS9.0000562152. 07779.48
33. Park JH, Riviere I, Gonen M, Wang X, Senechal B, Curran KJ, et al. Longterm follow-up of CD19 CAR therapy in acute lymphoblastic leukemia. $N$ Engl J Med. (2018) 378:449-59. doi: 10.1056/NEJMoa1709919

34. Hay KA, Gauthier J, Hirayama AV, Voutsinas JM, Wu Q, Li D, et al. Factors associated with durable EFS in adult B-cell ALL patients achieving MRD-negative CR after CD19 CAR T-cell therapy. Blood. (2019) 133:1652. doi: 10.1182/blood-2018-11-883710

35. Hirayama AV, Gauthier J, Hay KA, Voutsinas JM, Wu Q, Pender $\mathrm{BS}$, et al. High rate of durable complete remission in follicular lymphoma after CD19 CAR-T cell immunotherapy. Blood. (2019) 134:63640. doi: 10.1182/blood.2019000905

36. Ying Z, Huang XF, Xiang X, Liu Y, Kang X, Song Y, et al. A safe and potent anti-CD19 CAR T cell therapy. Nat Med. (2019) 25:94753. doi: $10.1038 / \mathrm{s} 41591-019-0421-7$

37. Jain T, Sauter CS, Shah GL, Maloy MA, Chan J, Scordo M, et al. Safety and feasibility of chimeric antigen receptor $\mathrm{T}$ cell therapy after allogeneic hematopoietic cell transplantation in relapsed/ refractory B cell non-Hodgkin lymphoma. Leukemia. (2019) 33:2540-4. doi: 10.1038/s41375-019-0476-y

38. Pan J, Yang JF, Deng BP, Zhao XJ, Zhang X, Lin YH, et al. High efficacy and safety of low-dose CD19-directed CAR-T cell therapy in 51 refractory or relapsed B acute lymphoblastic leukemia patients. Leukemia. (2017) 31:2587-93. doi: 10.1038/leu.2017.145

39. Xiao L, Huang H, Huang X, Ke X, Hu Y, Li J, et al. Efficacy of anti$\mathrm{CD} 19$ chimeric antigen receptor modified $\mathrm{T}(\mathrm{CAR}-\mathrm{T})$ cell therapy in Chinese patients with relapsed/refractory acute lymphocytic leukemia in a multicenter trial. J Clin Oncol. (2017) 35(Suppl 15):7028. doi: 10.1200/JCO.2017.35.15_suppl.7028

40. Lee DW, Kochenderfer JN, Stetler-Stevenson M, Cui YK, Delbrook $\mathrm{C}$, Feldman SA, et al. T cells expressing CD19 chimeric antigen receptors for acute lymphoblastic leukaemia in children and young adults: a phase 1 dose-escalation trial. Lancet. (2015) 385:517-28. doi: 10.1016/S0140-6736(14)61403-3

41. Gardner RA, Finney O, Annesley C, Brakke H, Summers C, Leger K, et al. Intent-to-treat leukemia remission by CD19 CAR T cells of defined formulation and dose in children and young adults. Blood. (2017) 129:332231. doi: 10.1182/blood-2017-02-769208

42. Turtle CJ, Hanafi LA, Berger C, Gooley TA, Cherian S, Hudecek M, et al. CD19 CAR-T cells of defined CD4+:CD8+ composition in adult B cell all patients. J Clin Invest. (2016) 126:2123-38. doi: 10.1172/JCI85309

43. Benjamin R, Graham C, Yallop D, Jozwik A, Ciocarlie O, Jain N, et al. Preliminary data on safety, cellular kinetics and anti-leukemic activity of UCART19, an allogeneic anti-CD19 CAR T-cell product, in a pool of adult and pediatric patients with high-risk CD19+ relapsed/refractory B-Cell acute lymphoblastic leukemia. Blood. (2018) 132(Suppl. 1):896. doi: 10.1182/blood-2018-99-111356

44. Fry TJ, Shah NN, Orentas RJ, Stetler-Stevenson M, Yuan CM, Ramakrishna $\mathrm{S}$, et al. CD22-targeted CAR T cells induce remission in B-ALL that is naive or resistant to CD19-targeted CAR immunotherapy. Nat Med. (2018) 24:20-8. doi: 10.1038/nm.4441

45. Lee DW, Gardner R, Porter DL, Louis CU, Ahmed N, Jensen M, et al. Current concepts in the diagnosis and management of cytokine release syndrome. Blood. (2014) 124:188-95. doi: 10.1182/blood-2014-05-552729

46. Siddiqi T, Abramson JS, Lee HJ, Schuster S, Hasskarl J, Montheard $\mathrm{S}$, et al. Safety of lisocabtagene maraleucel given with durvalumab in patients with relapsed/refractory aggressive B-cell non hodgkin lymphoma: first results from the platform study. Hematol Oncol. (2019) 37:1712. doi: $10.1002 /$ hon.128_2629

47. Hirayama AV, Gauthier J, Hay KA, Sheih A, Cherian S, Chen $\mathrm{X}$, et al. Efficacy and toxicity of JCAR014 in combination with durvalumab for the treatment of patients with relapsed/refractory aggressive B-cell non-hodgkin lymphoma. Blood. (2018) 132(Suppl. 1):1680. doi: 10.1182/blood-2018-99-116745

48. Till BG, Jensen MC, Wang J, Chen EY, Wood BL, Greisman HA, et al. Adoptive immunotherapy for indolent non-Hodgkin lymphoma and mantle cell lymphoma using genetically modified autologous CD20-specific $\mathrm{T}$ cells. Blood. (2008) 112:2261-71. doi: 10.1182/blood-2007-12-128843 
49. Till BG, Jensen MC, Wang J, Qian X, Gopal AK, Maloney DG, et al. CD20specific adoptive immunotherapy for lymphoma using a chimeric antigen receptor with both $\mathrm{CD} 28$ and $4-1 \mathrm{BB}$ domains: pilot clinical trial results. Blood. (2012) 119:3940-50. doi: 10.1182/blood-2011-10-387969

50. Siddiqi T, Dorritie KA, Soumerai JD, Stephens DM, Dubovsky JA, Gillenwater $\mathrm{HH}$, et al. TRANSCEND CLL 004: Minimal Residual Disease (MRD) negative responses after lisocabtagene maraleucel (LisoCel; JCAR017), a CD19-directed CAR $\mathrm{T}$ cell product, in patients (pts) with relapsed/refractory chronic lymphocytic leukemia or small lymphocytic lymphoma (CLL/SLL). J Clin Oncol. (2019) 37(Suppl. 15):7501. doi: 10.1200/JCO.2019.37.15_suppl.7501

51. Gill SI, Vides V, Frey NV, Metzger S, Brien M, Hexner E, et al. Prospective clinical trial of anti-CD19 CAR T cells in combination with ibrutinib for the treatment of chronic lymphocytic leukemia shows a high response rate. Blood. (2018) 132(Suppl. 1):298. doi: 10.1182/blood-2018-99-115418

52. Turtle CJ, Hay KA, Hanafi LA, Li D, Cherian S, Chen X, et al. Durable molecular remissions in chronic lymphocytic leukemia treated with CD19specific chimeric antigen receptor-modified t cells after failure of ibrutinib. $J$ Clin Oncol. (2017) 35:3010-20. doi: 10.1200/JCO.2017.72.8519

53. Giavridis T, van der Stegen SJC, Eyquem J, Hamieh M, Piersigilli A, Sadelain M. CAR T cell-induced cytokine release syndrome is mediated by macrophages and abated by IL-1 blockade. Nat Med. (2018) 24:7318. doi: 10.1038/s41591-018-0041-7

54. Norelli M, Camisa B, Barbiera G, Falcone L, Purevdorj A, Genua M, et al. Monocyte-derived IL-1 and IL-6 are differentially required for cytokinerelease syndrome and neurotoxicity due to CAR T cells. Nat Med. (2018) 24:739-48. doi: 10.1038/s41591-018-0036-4

55. Shimabukuro-Vornhagen A, Godel P, Subklewe M, Stemmler HJ, Schlosser HA, Schlaak M, et al. Cytokine release syndrome. I Immunother Cancer. (2018) 6:56. doi: 10.1186/s40425-018-0343-9

56. Neelapu SS, Tummala S, Kebriaei P, Wierda W, Gutierrez C, Locke FL, et al. Chimeric antigen receptor T-cell therapy - assessment and management of toxicities. Nat Rev Clin Oncol. (2018) 15:4762. doi: $10.1038 /$ nrclinonc. 2017.148

57. Lee DW, Santomasso BD, Locke FL, Ghobadi A, Turtle CJ, Brudno JN, et al. ASTCT consensus grading for cytokine release syndrome and neurologic toxicity associated with immune effector cells. Biol Blood Marrow Transplant. (2019) 25:625-38. doi: 10.1016/j.bbmt.2018.12.758

58. Locke FL, Neelapu SS, Bartlett NL, Lekakis LJ, Jacobson CA, Braunschweig I, et al. Preliminary results of prophylactic tocilizumab after axicabtageneciloleucel (axi-cel; KTE-C19) treatment for patients with refractory,aggressive Non-Hodgkin Lymphoma (NHL). Blood. (2017) 130(Suppl. 1):1547. doi: 10.1002/hon.2437_7

59. Liu S, Deng B, Yin Z, Pan J, Lin Y, Ling Z, et al. Corticosteroids do not influence the efficacy and kinetics of CAR-T cells for B-cell acute lymphoblastic leukemia. Blood Cancer J. (2020) 10:15. doi: 10.1038/s41408-020-0280-y

60. Gardner RA, Ceppi F, Rivers J, Annesley C, Summers C, Taraseviciute A, et al. Preemptive mitigation of CD19 CAR T-cell cytokine release syndrome without attenuation of antileukemic efficacy. Blood. (2019) 134:214958. doi: 10.1182/blood.2019001463

61. Chou CK, Turtle CJ. Assessment and management of cytokine release syndrome and neurotoxicity following CD19 CAR-T cell therapy. Expert Opin Biol Ther. (2020) 24:1-12. doi: 10.1080/14712598.2020.1729735

62. Yáñez L, Sánchez-Escamilla $M$, Perales M-A. CAR T cell toxicity: current management and future directions. HemaSphere. (2019) 3:e186. doi: 10.1097/HS9.0000000000000186

63. Ruella M, Kenderian SS, Shestova O, Klichinsky M, Melenhorst JJ, Wasik $\mathrm{MA}$, et al. Kinase inhibitor ibrutinib prevents cytokine-release syndrome after Anti-CD19 chimeric antigen receptor $\mathrm{T}$ cells (CART) for B cell neoplasms. Blood. (2016) 128:2159. doi: 10.1182/blood.V128.22.2159.2159

64. Mestermann K, Giavridis T, Weber J, Rydzek J, Frenz S, Nerreter $\mathrm{T}$, et al. The tyrosine kinase inhibitor dasatinib acts as a pharmacologic on/off switch for CAR T cells. Sci Transl Med. (2019) 11:aau5907. doi: 10.1126/scitranslmed.aau5907

65. Weber EW, Lynn RC, Sotillo E, Lattin J, Xu P, Mackall CL. Pharmacologic control of CAR-T cell function using dasatinib. Blood Adv. (2019) 3:7117. doi: 10.1182/bloodadvances.2018028720
66. Frey NV, Shaw PA, Hexner EO, Pequignot E, Gill S, Luger SM, et al. Optimizing chimeric antigen receptor T-cell therapy for adults with acute lymphoblastic leukemia. J Clin Oncol. (2019) 34(Suppl. 15):7002. doi: 10.1200/JCO.2016.34.15_suppl.7002

67. Gust J, Hay KA, Hanafi LA, Li D, Myerson D, Gonzalez-Cuyar LF, et al. Endothelial activation and blood-brain barrier disruption in neurotoxicity after adoptive immunotherapy with CD19 CAR-T Cells. Cancer Dis. (2017) 7:1404-19. doi: 10.1158/2159-8290.CD-17-0698

68. Taraseviciute A, Tkachev V, Ponce R, Turtle CJ, Snyder JM, Liggitt HD, et al. Chimeric antigen receptor T cell-mediated neurotoxicity in nonhuman primates. Cancer Dis. (2018) 8:750-63. doi: 10.1158/2159-8290.CD-17-1368

69. Neelapu SS. Managing the toxicities of CAR T-cell therapy. Hematol Oncol. (2019) 37(Suppl. 1):48-52. doi: 10.1002/hon.2595

70. Sterner RM, Sakemura R, Cox MJ, Yang N, Khadka RH, Forsman $\mathrm{CL}$, et al. GM-CSF inhibition reduces cytokine release syndrome and neuroinflammation but enhances CAR-T cell function in xenografts. Blood. (2019) 133:697-709. doi: 10.1182/blood-2018-10-881722

71. Fried S, Avigdor A, Bielorai B, Meir A, Besser MJ, Schachter J, et al. Early and late hematologic toxicity following CD19 CAR-T cells. Bone Marrow Transplant. (2019) 54(Suppl. 1): 1643-50. doi: 10.1038/s41409-019-0487-3

72. Davila ML, Riviere I, Wang X, Bartido S, Park J, Curran K, et al. Efficacy and toxicity management of $19-28 \mathrm{z}$ CAR $\mathrm{T}$ cell therapy in B cell acute lymphoblastic leukemia. Sci Transl Med. (2014) 6:224ra25. doi: 10.1126/scitranslmed.3008226

73. Turtle CJ, Hanafi LA, Berger C, Hudecek M, Pender B, Robinson E, et al. Immunotherapy of non-Hodgkin's lymphoma with a defined ratio of CD8+ and CD4+ CD19-specific chimeric antigen receptor-modified T cells. Sci Transl Med. (2016) 8:355ra116. doi: 10.1126/scitranslmed.aaf8621

74. Hu Y, Wu Z, Luo Y, Shi J, Yu J, Pu C, et al. Potent anti-leukemia activities of chimeric antigen receptor-modified t cells against CD19 in chinese patients with relapsed/refractory acute lymphocytic leukemia. Clin Can Res. (2017) 23:3297-306. doi: 10.1158/1078-0432.CCR-16-1799

75. Santomasso B, Bachier C, Westin J, Rezvani K, Shpall EJ. The other side of CAR T-cell Therapy: cytokine release syndrome, neurologic toxicity, and financial burden. Am Soc Clin Oncol Educ Book. (2019) 39:43344. doi: 10.1200/EDBK_238691

76. Hay KA, Hanafi LA, Li D, Gust J, Liles WC, Wurfel MM, et al. Kinetics and biomarkers of severe cytokine release syndrome after CD19 chimeric antigen receptor-modified T-cell therapy. Blood. (2017) 130:2295306. doi: 10.1182/blood-2017-06-793141

77. Alabanza L, Pegues M, Geldres C, Shi V, Wiltzius JJW, Sievers SA, et al. Function of novel anti-CD19 chimeric antigen receptors with human variable regions is affected by hinge and transmembrane domains. Mol. Ther. (2017) 25:2452-65. doi: 10.1016/j.ymthe.2017.07.013

78. Kochenderfer JN, Somerville RPT, Lu T, Shi V, Bot A, Rossi J, et al. Lymphoma remissions caused by anti-CD19 chimeric antigen receptor $\mathrm{T}$ cells are associated with high serum interleukin-15 levels. J Clin Oncol. (2017) 35:1803-13. doi: 10.1200/JCO.2016.71.3024

79. Teachey DT, Lacey SF, Shaw PA, Melenhorst JJ, Maude SL, Frey N, et al. Identification of predictive biomarkers for cytokine release syndrome after chimeric antigen receptor t-cell therapy for acute lymphoblastic leukemia. Cancer Discov. (2016) 6:664-79. doi: 10.1158/2159-8290.CD-16-0040

80. Karschnia P, Jordan JT, Forst DA, Arrillaga-Romany IC, Batchelor TT, Baehring JM, et al. Clinical presentation, management, and biomarkers of neurotoxicity after adoptive immunotherapy with CAR T cells. Blood. (2019) 133:2212-21. doi: 10.1182/blood-2018-12-893396

81. Faramand R, Kotani H, Morrissey D, Yu B, Locke FL, Jain MD, et al. Prediction of CAR T-related toxicities in R/R DLBCL patients treated with axicabtagene ciloleucel using point of care cytokine measurements. Blood. (2018) 132(Suppl. 1):95. doi: 10.1182/blood-2018-99116539

82. Santomasso BD, Park JH, Salloum D, Riviere I, Flynn J, Mead E, et al. Clinical and biological correlates of neurotoxicity associated with CAR T-cell therapy in patients with B-cell acute lymphoblastic leukemia. Cancer Discov. (2018) 8:958-71. doi: 10.1158/2159-8290.CD-17-1319

83. Salter AI, Pont MJ, Riddell SR. Chimeric antigen receptormodified T cells: CD19 and the road beyond. Blood. (2018) 131:2621-9. doi: 10.1182/blood-2018-01-785840 
84. Shalabi H, Kraft IL, Wang HW, Yuan CM, Yates B, Delbrook C, et al. Sequential loss of tumor surface antigens following chimeric antigen receptor T-cell therapies in diffuse large B-cell lymphoma. Haematologica. (2018) 103:e215-e8. doi: 10.3324/haematol.2017.183459

85. Neelapu SS, Rossi JM, Jacobson CA, Locke FL, Miklos DB, Reagan PM, et al. CD19-loss with preservation of other B cell lineage features in patients with large B cell lymphoma who relapsed post-axi-cel. Blood. (2019) 134(Suppl. 1):203. doi: 10.1182/blood-2019-126218

86. Sotillo E, Barrett DM, Black KL, Bagashev A, Oldridge D, Wu G, et al. Convergence of acquired mutations and alternative splicing of CD19 enables resistance to CART-19 immunotherapy. Cancer Discov. (2015) 5:128295. doi: 10.1158/2159-8290.CD-15-1020

87. van Zelm MC, Reisli I, van der Burg M, Castano D, van Noesel CJ, van Tol MJ, et al. An antibody-deficiency syndrome due to mutations in the CD19 gene. N Engl J Med. (2006) 354:1901-12. doi: 10.1056/NEJMoa051568

88. Orlando EJ, Han X, Tribouley C, Wood PA, Leary RJ, Riester M, et al. Genetic mechanisms of target antigen loss in CAR19 therapy of acute lymphoblastic leukemia. Nat Med. (2018) 24:1504-6. doi: 10.1038/s41591-018-0146-Z

89. Grada Z, Hegde M, Byrd T, Shaffer DR, Ghazi A, Brawley VS, et al. TanCAR: a novel bispecific chimeric antigen receptor for cancer immunotherapy. $\mathrm{Mol}$ Ther Nucleic Acids. (2013) 2:e105. doi: 10.1038/mtna.2013.32

90. Hegde M, Corder A, Chow KK, Mukherjee M, Ashoori A, Kew Y, et al. Combinational targeting offsets antigen escape and enhances effector functions of adoptively transferred T cells in glioblastoma. Mol Ther. (2013) 21:2087-101. doi: 10.1038/mt.2013.185

91. Ruella M, Xu J, Barrett DM, Fraietta JA, Reich TJ, Ambrose DE, et al. Induction of resistance to chimeric antigen receptor $\mathrm{T}$ cell therapy by transduction of a single leukemic B cell. Nat Med. (2018) 24:1499503. doi: 10.1038/s41591-018-0201-9

92. Ruella M, Barrett DM, Shestova O, Perazzelli J, Posey AD, Hong SJ, et al. A cellular antidote to specifically deplete anti-CD19 chimeric antigen receptor positive cells. Blood. (2019) 135:505-9. doi: 10.1182/blood.2019001859

93. Gardner R, Wu D, Cherian S, Fang M, Hanafi LA, Finney O, et al. Acquisition of a CD19-negative myeloid phenotype allows immune escape of MLLrearranged B-ALL from CD19 CAR-T-cell therapy. Blood. (2016) 127:240610. doi: 10.1182/blood-2015-08-665547

94. Jacoby E, Nguyen SM, Fountaine TJ, Welp K, Gryder B, Qin H, et al. CD19 CAR immune pressure induces B-precursor acute lymphoblastic leukaemia lineage switch exposing inherent leukaemic plasticity. Nat Commun. (2016) 7:12320. doi: $10.1038 /$ ncomms 12320

95. Shah NN, Fry TJ. Mechanisms of resistance to CAR T cell therapy. Nat Rev Clin Oncol. (2019) 16:372-85. doi: 10.1038/s41571-019-0184-6

96. Fraietta JA, Lacey SF, Orlando EJ, Pruteanu-Malinici I, Gohil M, Lundh S, et al. Determinants of response and resistance to CD19 chimeric antigen receptor (CAR) T cell therapy of chronic lymphocytic leukemia. Nat Med. (2018) 24:563-71. doi: 10.1038/s41591-018-0010-1

97. Brudno JN, Shi V, Stroncek D, Pittaluga S, Kanakry JA, Curtis LM, et al. T cells expressing a novel fully-human anti-CD19 chimeric antigen receptor induce remissions of advanced lymphoma in a first-in-humans clinical trial. Blood. (2016) 128:999. doi: 10.1182/blood.V128.22.999.999

98. Coscia M, Vitale C, Cerrano M, Maffini E, Giaccone L, Boccadoro M, et al. Adoptive immunotherapy with CAR modified T cells in cancer: current landscape and future perspectives. Front Biosci (Landmark Ed). (2019) 24:1284-315. doi: $10.2741 / 4780$

99. Haso W, Lee DW, Shah NN, Stetler-Stevenson M, Yuan CM, Pastan IH, et al. Anti-CD22-chimeric antigen receptors targeting B-cell precursor acute lymphoblastic leukemia. Blood. (2013) 121:1165-74. doi: 10.1182/blood-2012-06-438002

100. James SE, Greenberg PD, Jensen MC, Lin Y, Wang J, Till BG, et al. Antigen sensitivity of CD22-specific chimeric TCR Is modulated by target epitope distance from the cell membrane. J Immunol. (2008) 180:702838. doi: 10.4049/jimmunol.180.10.7028

101. Ramakrishna S, Highfill SL, Walsh Z, Nguyen SM, Lei H, Shern JF, et al. Modulation of target antigen density improves CAR T-cell functionality and persistence. Clin Cancer Res. (2019) 25:5329-41. doi: 10.1158/1078-0432.CCR-18-3784
102. Ramos CA, Savoldo B, Torrano V, Ballard B, Zhang H, Dakhova O, et al. Clinical responses with $\mathrm{T}$ lymphocytes targeting malignancy-associated kappa light chains. J Clin Invest. (2016) 126:2588-96. doi: 10.1172/JCI86000

103. Baskar S, Kwong KY, Hofer T, Levy JM, Kennedy MG, Lee E, et al. Unique cell surface expression of receptor tyrosine kinase ROR1 in human B-cell chronic lymphocytic leukemia. Clin Cancer Res. (2008) 14:396404. doi: 10.1158/1078-0432.CCR-07-1823

104. Daneshmanesh AH, Mikaelsson E, Jeddi-Tehrani M, Bayat AA, Ghods R, Ostadkarampour M, et al. Ror1, a cell surface receptor tyrosine kinase is expressed in chronic lymphocytic leukemia and may serve as a putative target for therapy. Int J Cancer. (2008) 123:1190-5. doi: 10.1002/ijc.23587

105. Gentile A, Lazzari L, Benvenuti S, Trusolino L, Comoglio PM. Ror1 is a pseudokinase that is crucial for Met-driven tumorigenesis. Cancer Res. (2011) 71:3132-41. doi: 10.1158/0008-5472.CAN-10-2662

106. Hudecek M, Schmitt TM, Baskar S, Lupo-Stanghellini MT, Nishida T, Yamamoto TN, et al. The B-cell tumor-associated antigen ROR1 can be targeted with T cells modified to express a ROR1-specific chimeric antigen receptor. Blood. (2010) 116:4532-41. doi: 10.1182/blood-2010-05-283309

107. Berger C, Sommermeyer D, Hudecek M, Berger M, Balakrishnan A, Paszkiewicz PJ, et al. Safety of targeting ROR1 in primates with chimeric antigen receptor-modified $\mathrm{T}$ cells. Cancer immunology research. (2015) 3:206-16. doi: 10.1158/2326-6066.CIR-14-0163

108. Choi MY, Widhopf GF, 2nd, Ghia EM, Kidwell RL, Hasan MK, Yu J, et al. Phase I trial: cirmtuzumab inhibits ROR1 signaling and stemness signatures in patients with chronic lymphocytic leukemia. Cell Stem Cell. (2018) 22:951-9. doi: 10.1016/j.stem.2018.05.018

109. Gohil SH, Paredes-Moscosso SR, Harrasser M, Vezzalini M, Scarpa A, Morris $\mathrm{E}$, et al. An ROR1 bi-specific T-cell engager provides effective targeting and cytotoxicity against a range of solid tumors. Oncoimmunology. (2017) 6:e1326437. doi: 10.1080/2162402X.2017.1326437

110. Hojjat-Farsangi M, Daneshmanesh AH, Khan AS, Shetye J, Mozaffari F, Kharaziha P, et al. First-in-class oral small molecule inhibitor of the tyrosine kinase ROR1 (KAN0439834) induced significant apoptosis of chronic lymphocytic leukemia cells. Leukemia. (2018) 32:22915. doi: 10.1038/s41375-018-0113-1

111. Koksal H, Dillard P, Josefsson SE, Maggadottir SM, Pollmann $\mathrm{S}$, Fane A, et al. Preclinical development of CD37CAR T-cell therapy for treatment of B-cell lymphoma. Blood Adv. (2019) 3:1230-43. doi: 10.1182/bloodadvances.2018029678

112. Scarfo I, Ormhoj M, Frigault MJ, Castano AP, Lorrey S, Bouffard AA, et al. Anti-CD37 chimeric antigen receptor $\mathrm{T}$ cells are active against B- and T-cell lymphomas. Blood. (2018) 132:1495-506. doi: 10.1182/blood-2018-04-842708

113. Fesnak AD, June CH, Levine BL. Engineered T cells: the promise and challenges of cancer immunotherapy. Nat Rev Cancer. (2016) 16:56681. doi: $10.1038 /$ nrc. 2016.97

114. Anurathapan U, Chan RC, Hindi HF, Mucharla R, Bajgain P, Hayes $\mathrm{BC}$, et al. Kinetics of tumor destruction by chimeric antigen receptormodified T cells. Mol Ther. (2014) 22:623-33. doi: 10.1038/mt. 2013.262

115. Hegde M, Mukherjee M, Grada Z, Pignata A, Landi D, Navai SA, et al. Tandem CAR T cells targeting HER2 and IL13Ralpha2 mitigate tumor antigen escape. J Clin Invest. (2016) 126:3036-52. doi: 10.1172/JCI83416

116. Ruella M, Barrett DM, Kenderian SS, Shestova O, Hofmann TJ, Perazzelli J, et al. Dual CD19 and CD123 targeting prevents antigen-loss relapses after CD19-directed immunotherapies. J Clin Invest. (2016) 126:381426. doi: 10.1172/JCI87366

117. Zah E, Lin MY, Silva-Benedict A, Jensen MC, Chen YY. T cells expressing CD19/CD20 bispecific chimeric antigen receptors prevent antigen escape by malignant B cells. Can Immunol Res. (2016) 4:498508. doi: 10.1158/2326-6066.CIR-15-0231

118. Shah NN, Zhu F, Schneider D, Taylor C, Krueger W, Worden A, et al. Results of a phase I study of bispecific anti-CD19, antiCD20 chimeric antigen receptor (CAR) modified $T$ cells for relapsed, refractory, non-Hodgkin lymphoma. J Clin Oncol. (2019) 37(15_suppl):2510. doi: 10.1200/JCO.2019.37.15_suppl.2510 
119. Qin H, Haso W, Nguyen SM, Fry TJ. Preclinical development of bispecific chimeric antigen receptor targeting both CD19 and CD22. Blood. (2015) 126:4427. doi: 10.1182/blood.V126.23.4427.4427

120. John LB, Devaud C, Duong CP, Yong CS, Beavis PA, Haynes NM, et al. Anti-PD-1 antibody therapy potently enhances the eradication of established tumors by gene-modified T cells. Clin Cancer Res. (2013) 19:5636-46. doi: 10.1158/1078-0432.CCR-13-0458

121. Cherkassky L, Morello A, Villena-Vargas J, Feng Y, Dimitrov DS, Jones $\mathrm{DR}$, et al. Human CAR T cells with cell-intrinsic PD-1 checkpoint blockade resist tumor-mediated inhibition. J Clin Invest. (2016) 126:313044. doi: 10.1172/JCI83092

122. John LB, Kershaw MH, Darcy PK. Blockade of PD-1 immunosuppression boosts CAR T-cell therapy. Oncoimmunology. (2013) 2:e26286. doi: $10.4161 /$ onci.26286

123. Moon EK, Ranganathan R, Eruslanov E, Kim S, Newick K, O'Brien S, et al. Blockade of programmed death 1 augments the ability of human $t$ cells engineered to target NY-ESO-1 to control tumor growth after adoptive transfer. Clin Cancer Res. (2016) 22:436-47. doi: 10.1158/1078-0432.CCR-15-1070

124. Jacobson CA, Locke FL, Miklos DB, Herrera AF, Westin JR, Lee J, et al. End of phase 1 results from zuma-6: axicabtagene ciloleucel (AxiCel) in combination with atezolizumab for the treatment of patients with refractory diffuse large B cell Lymphoma. Blood. (2018) 132(Suppl. 1):4192. doi: 10.1182/blood-2018-99-111523

125. Chong EA, Melenhorst JJ, Lacey SF, Ambrose DE, Gonzalez V, Levine BL, et al. PD-1 blockade modulates chimeric antigen receptor (CAR)-modified T cells: refueling the CAR. Blood. (2017) 129:1039-41. doi: 10.1182/blood-2016-09-738245

126. Audrito V, Serra S, Brusa D, Mazzola F, Arruga F, Vaisitti T, et al. Extracellular nicotinamide phosphoribosyltransferase (NAMPT) promotes M2 macrophage polarization in chronic lymphocytic leukemia. Blood. (2015) 125:111-23. doi: 10.1182/blood-2014-07-589069

127. Brusa D, Serra S, Coscia M, Rossi D, D’Arena G, Laurenti L, et al. The PD-1/PD-L1 axis contributes to T-cell dysfunction in chronic lymphocytic leukemia. Haematologica. (2013) 98:953-63. doi: 10.3324/haematol.2012.077537

128. Coscia M, Vitale C, Peola S, Foglietta M, Rigoni M, Griggio $\mathrm{V}$, et al. Dysfunctional Vgamma9Vdelta2 $\mathrm{T}$ cells are negative prognosticators and markers of dysregulated mevalonate pathway activity in chronic lymphocytic leukemia cells. Blood. (2012) 120:3271-9. doi: 10.1182/blood-2012-03-417519

129. D’Arena G, Vitale C, Coscia M, Festa A, Di Minno NMD, De Feo $V$, et al. Regulatory $\mathrm{T}$ cells and their prognostic relevance in hematologic malignancies. J Immunol Res. (2017) 2017:1832968. doi: 10.1155/2017/1832968

130. Rizzo R, Audrito V, Vacca P, Rossi D, Brusa D, Stignani M, et al. HLA-G is a component of the chronic lymphocytic leukemia escape repertoire to generate immune suppression: impact of the HLA-G 14 base pair (rs66554220) polymorphism. Haematologica. (2014) 99:88896. doi: 10.3324/haematol.2013.095281

131. Chen SS, Chang BY, Chang S, Tong T, Ham S, Sherry B, et al. BTK inhibition results in impaired CXCR 4 chemokine receptor surface expression, signaling and function in chronic lymphocytic leukemia. Leukemia. (2016) 30:83343. doi: 10.1038/leu.2015.316

132. Natarajan G, Terrazas C, Oghumu S, Varikuti S, Dubovsky JA, Byrd JC, et al. Ibrutinib enhances IL-17 response by modulating the function of bone marrow derived dendritic cells. Oncoimmunology. (2016) 5:e1057385. doi: 10.1080/2162402X.2015.1057385

133. Niemann CU, Herman SE, Maric I, Gomez-Rodriguez J, Biancotto A, Chang BY, et al. Disruption of in vivo chronic lymphocytic leukemia tumor-microenvironment interactions by ibrutinib-findings from an investigator-initiated phase II study. Clin Cancer Res. (2016) 22:157282. doi: 10.1158/1078-0432.CCR-15-1965

134. Griggio V, Vitale C, Todaro M, Mauro FR, Salvetti C, Pietrasanta D, et al. Ibrutinib treatment mitigates phenotypic alterations of non-neoplastic immune cell compartments in chronic lymphocytic leukemia. Blood. (2018) 132(Suppl. 1):4412. doi: 10.1182/blood-2018-99-116068
135. Fraietta JA, Beckwith KA, Patel PR, Ruella M, Zheng Z, Barrett DM, et al. Ibrutinib enhances chimeric antigen receptor T-cell engraftment and efficacy in leukemia. Blood. (2016) 127:1117-27. doi: 10.1182/blood-2015-11-679134

136. Ruella M, Kenderian SS, Shestova O, Fraietta JA, Qayyum S, Zhang $\mathrm{Q}$, et al. The addition of the BTK inhibitor ibrutinib to antiCD19 Chimeric Antigen Receptor T Cells (CART19) improves responses against mantle cell lymphoma. Clin Cancer Res. (2016) 22:2684-96. doi: 10.1158/1078-0432.CCR-15-1527

137. Galustian C, Meyer B, Labarthe MC, Dredge K, Klaschka D, Henry J, et al. The anti-cancer agents lenalidomide and pomalidomide inhibit the proliferation and function of $\mathrm{T}$ regulatory cells. Cancer Immunol Immunother CII. (2009) 58:1033-45. doi: 10.1007/s00262-008-0620-4

138. Neuber B, Dai J, Waraich WA, Awwad MHS, Engelhardt M, Schmitt $M$, et al. Lenalidomide overcomes the immunosuppression of regulatory CD8(+)CD28(-) T-cells. Oncotarget. (2017) 8:98200-14. doi: 10.18632/oncotarget.21516

139. Wang X, Walter M, Urak R, Weng L, Huynh C, Lim L, et al. Lenalidomide enhances the function of CS1 chimeric antigen receptorredirected T cells against multiple myeloma. Clin Cancer Res. (2018) 24:10619. doi: 10.1158/1078-0432.CCR-17-0344

140. Ruella M, Klichinsky M, Kenderian SS, Shestova O, Ziober A, Kraft DO, et al. Overcoming the immunosuppressive tumor microenvironment of hodgkin lymphoma using chimeric antigen receptor T cells. Cancer Discov. (2017) 7:1154-67. doi: 10.1158/2159-8290.CD-16-0850

141. Nishio N, Diaconu I, Liu H, Cerullo V, Caruana I, Hoyos V, et al. Armed oncolytic virus enhances immune functions of chimeric antigen receptor-modified T cells in solid tumors. Cancer Res. (2014) 74:5195205. doi: 10.1158/0008-5472.CAN-14-0697

142. Watanabe K, Luo Y, Da T, Guedan S, Ruella M, Scholler J, et al. Pancreatic cancer therapy with combined mesothelin-redirected chimeric antigen receptor T cells and cytokine-armed oncolytic adenoviruses. JCI Insight. (2018) 3:99753. doi: $10.1172 /$ jci.insight.99573

143. Tanoue K, Rosewell Shaw A, Watanabe N, Porter C, Rana B, Gottschalk $\mathrm{S}$, et al. Armed oncolytic adenovirus-expressing pd-11 mini-body enhances antitumor effects of chimeric antigen receptor T cells in solid tumors. Cancer Res. (2017) 77:2040-51. doi: 10.1158/0008-5472.CAN-16-1577

144. Fajardo CA, Guedan S, Rojas LA, Moreno R, Arias-Badia M, de Sostoa J, et al. Oncolytic adenoviral delivery of an EGFR-targeting Tcell engager improves antitumor efficacy. Cancer Res. (2017) 77:205263. doi: 10.1158/0008-5472.CAN-16-1708

145. Wing A, Fajardo CA, Posey AD, Jr, Shaw C, Da T, Young RM, et al. Improving CART-cell therapy of solid tumors with oncolytic virus-driven production of a bispecific T-cell engager. Cancer Immunol Res. (2018) 6:605-16. doi: 10.1158/2326-6066.CIR-17-0314

146. Cohen J. IL-12 deaths: explanation and a puzzle. Science. (1995) 270:908. doi: 10.1126/science.270.5238.908a

147. Chmielewski M, Kopecky C, Hombach AA, Abken H. IL-12 release by engineered $\mathrm{T}$ cells expressing chimeric antigen receptors can effectively muster an antigen-independent macrophage response on tumor cells that have shut down tumor antigen expression. Cancer Res. (2011) 71:5697706. doi: 10.1158/0008-5472.CAN-11-0103

148. Koneru M, O'Cearbhaill R, Pendharkar S, Spriggs DR, Brentjens RJ. A phase I clinical trial of adoptive T cell therapy using IL-12 secreting MUC-16(ecto) directed chimeric antigen receptors for recurrent ovarian cancer. $J$ Transl Med. (2015) 13:102. doi: 10.1186/s12967-015-0460-x

149. Pegram HJ, Lee JC, Hayman EG, Imperato GH, Tedder TF, Sadelain M, et al. Tumor-targeted T cells modified to secrete IL-12 eradicate systemic tumors without need for prior conditioning. Blood. (2012) 119:413341. doi: 10.1182/blood-2011-12-400044

150. Hoyos V, Savoldo B, Quintarelli C, Mahendravada A, Zhang M, Vera J, et al. Engineering CD19-specific T lymphocytes with interleukin-15 and a suicide gene to enhance their anti-lymphoma/leukemia effects and safety. Leukemia. (2010) 24:1160-70. doi: 10.1038/leu.2010.75

151. Hurton LV, Singh H, Najjar AM, Switzer KC, Mi T, Maiti S, et al. Tethered IL-15 augments antitumor activity and promotes a stem-cell memory subset in tumor-specific T cells. Proc Natl Acad Sci USA. (2016) 113:E778897. doi: $10.1073 /$ pnas.1610544113 
152. Krenciute G, Prinzing BL, Yi Z, Wu MF, Liu H, Dotti G, et al. Transgenic expression of IL15 improves antiglioma activity of IL13Ralpha2-CAR T cells but results in antigen loss variants. Cancer Immunol Res. (2017) 5:57181. doi: 10.1158/2326-6066.CIR-16-0376

153. Chmielewski M, Abken H. CAR T cells releasing IL-18 convert to T-bet(high) FoxO1(low) effectors that exhibit augmented activity against advanced solid tumors. Cell Rep. (2017) 21:3205-19. doi: 10.1016/j.celrep.2017.11.063

154. Hu B, Ren J, Luo Y, Keith B, Young RM, Scholler J, et al. Augmentation of antitumor immunity by human and mouse CAR T cells secreting IL-18. Cell Rep. (2017) 20:3025-33. doi: 10.1016/j.celrep.2017.09.002

155. Kunert A, Chmielewski M, Wijers R, Berrevoets C, Abken H, Debets R. Intratumoral production of IL18, but not IL12, by TCR-engineered T cells is nontoxic and counteracts immune evasion of solid tumors. Oncoimmunology. (2017) 7:e1378842. doi: 10.1080/2162402X.2017.1378842

156. Markley JC, Sadelain M. IL-7 and IL-21 are superior to IL2 and IL-15 in promoting human $\mathrm{T}$ cell-mediated rejection of systemic lymphoma in immunodeficient mice. Blood. (2010) 115:3508-19. doi: 10.1182/blood-2009-09-241398

157. Kagoya Y, Tanaka S, Guo T, Anczurowski M, Wang CH, Saso K, et al. A novel chimeric antigen receptor containing a JAK-STAT signaling domain mediates superior antitumor effects. Nat Med. (2018) 24:3529. doi: 10.1038/nm.4478

158. Foster AE, Dotti G, Lu A, Khalil M, Brenner MK, Heslop HE, et al. Antitumor activity of EBV-specific $\mathrm{T}$ lymphocytes transduced with a dominant negative TGF-beta receptor. J Immunother. (2008) 31:5005. doi: 10.1097/CJI.0b013e318177092b

159. Leen AM, Sukumaran S, Watanabe N, Mohammed S, Keirnan J, Yanagisawa $\mathrm{R}$, et al. Reversal of tumor immune inhibition using a chimeric cytokine receptor. Mol Ther. (2014) 22:1211-20. doi: 10.1038/mt.2014.47

160. Mohammed S, Sukumaran S, Bajgain P, Watanabe N, Heslop HE, Rooney $\mathrm{CM}$, et al. Improving chimeric antigen receptor-modified $\mathrm{T}$ cell function by reversing the immunosuppressive tumor microenvironment of pancreatic cancer. Mol Ther. (2017) 25:249-58. doi: 10.1016/j.ymthe.2016.10.016

161. Liu X, Ranganathan R, Jiang S, Fang C, Sun J, Kim S, et al. A chimeric switch-receptor targeting PD1 augments the efficacy of second-generation CAR T cells in advanced solid tumors. Cancer Res. (2016) 76:157890. doi: 10.1158/0008-5472.CAN-15-2524

162. Curran KJ, Seinstra BA, Nikhamin Y, Yeh R, Usachenko Y, van Leeuwen $\mathrm{DG}$, et al. Enhancing antitumor efficacy of chimeric antigen receptor $\mathrm{T}$ cells through constitutive CD40L expression. Mol Ther. (2015) 23:76978. doi: $10.1038 / \mathrm{mt} .2015 .4$

163. Zhao Z, Condomines M, van der Stegen SJC, Perna F, Kloss CC, Gunset $\mathrm{G}$, et al. Structural design of engineered costimulation determines tumor rejection kinetics and persistence of CAR T cells. Cancer Cell. (2015) 28:41528. doi: 10.1016/j.ccell.2015.09.004

164. Park JH, Palomba ML, Batlevi CL, Riviere I, Wang X, Senechal B, et al. A phase I first-in-human clinical trial of CD19-targeted 19-28z/4$1 B B L$ "Armored" CAR T cells in patients with relapsed or refractory NHL and CLL including richtes transformation. Blood. (2018) 132(Suppl. 1):224. doi: 10.1182/blood-2018-99-117737

165. Adachi K, Kano Y, Nagai T, Okuyama N, Sakoda Y, Tamada K. IL-7 and CCL19 expression in CAR-T cells improves immune cell infiltration and CAR-T cell survival in the tumor. Nature Biotechnol. (2018) 36:34651. doi: $10.1038 /$ nbt. 4086

166. di Stasi A, de Angelis B, Rooney CM, Zhang L, Mahendravada A, Foster AE, et al. $\mathrm{T}$ lymphocytes coexpressing CCR4 and a chimeric antigen receptor targeting CD30 have improved homing and antitumor activity in a Hodgkin tumor model. Blood. (2009) 113:6392-402. doi: 10.1182/blood-2009-03-209650

167. Suarez ER, Chang de K, Sun J, Sui J, Freeman GJ, Signoretti S, et al. Chimeric antigen receptor $\mathrm{T}$ cells secreting anti-PD-L1 antibodies more effectively regress renal cell carcinoma in a humanized mouse model. Oncotarget. (2016) 7:34341-55. doi: 10.18632/oncotarget.9114

168. Rafiq S, Yeku OO, Jackson HJ, Purdon TJ, van Leeuwen DG, Drakes DJ, et al. Targeted delivery of a PD-1-blocking scFv by CAR-T cells enhances anti-tumor efficacy in vivo. Nature Biotechnol. (2018) 36:84756. doi: $10.1038 /$ nbt.4195
169. Iwahori K, Kakarla S, Velasquez MP, Yu F, Yi Z, Gerken C, et al. Engager T cells: a new class of antigen-specific $\mathrm{T}$ cells that redirect bystander $\mathrm{T}$ cells. Mol Ther. (2015) 23:171-8. doi: 10.1038/mt.2014.156

170. Bonifant CL, Szoor A, Torres D, Joseph N, Velasquez MP, Iwahori K, et al. CD123-engager $\mathrm{T}$ cells as a novel immunotherapeutic for acute myeloid leukemia. Mol Ther. (2016) 24:1615-26. doi: 10.1038/mt.2016.116

171. Velasquez MP, Torres D, Iwahori K, Kakarla S, Arber C, RodriguezCruz $\mathrm{T}$, et al. $\mathrm{T}$ cells expressing CD19-specific engager molecules for the immunotherapy of CD19-positive malignancies. Sci Rep. (2016) 6:27130. doi: $10.1038 /$ srep27130

172. Perales MA, Kebriaei P, Kean LS, Sadelain M. Building a safer and faster CAR: seatbelts, airbags, and CRISPR. Biol Blood Marrow Transplant. (2018) 24:27-31. doi: 10.1016/j.bbmt.2017.10.017

173. Ahmadzadeh M, Johnson LA, Heemskerk B, Wunderlich JR, Dudley ME, White DE, et al. Tumor antigen-specific CD8 T cells infiltrating the tumor express high levels of PD-1 and are functionally impaired. Blood. (2009) 114:1537-44. doi: 10.1182/blood-2008-12-195792

174. Wherry EJ. T cell exhaustion. Nat Immunol. (2011) 12:4929. doi: $10.1038 /$ ni.2035

175. Frigault MJ, Lee J, Basil MC, Carpenito C, Motohashi S, Scholler J, et al. Identification of chimeric antigen receptors that mediate constitutive or inducible proliferation of T cells. Cancer Immunol Res. (2015) 3:35667. doi: 10.1158/2326-6066.CIR-14-0186

176. Eyquem J, Mansilla-Soto J, Giavridis T, van der Stegen SJ, Hamieh M, Cunanan KM, et al. Targeting a CAR to the TRAC locus with CRISPR/Cas9 enhances tumour rejection. Nature. (2017) 543:113-7. doi: 10.1038/nature21405

177. Viaud S, Ma JSY, Hardy IR, Hampton EN, Benish B, Sherwood L, et al. Switchable control over in vivo CAR $\mathrm{T}$ expansion, B cell depletion, and induction of memory. Proc Natl Acad Sci USA. (2018) 115:E10898906. doi: 10.1073/pnas.1810060115

178. Vitale C, Griggio V, Todaro M, Salvetti C, Boccadoro M, Coscia M. Magic pills: new oral drugs to treat chronic lymphocytic leukemia. Expert Opin Pharmacother. (2017) 18:411-25. doi: 10.1080/14656566.2017.1293655

179. Rigolin GM, Cavallari M, Quaglia FM, Formigaro L, Lista E, Urso A, et al. In CLL, comorbidities and the complex karyotype are associated with an inferior outcome independently of CLL-IPI. Blood. (2017) 129:34958. doi: 10.1182/blood-2017-03-772285

180. Lemal R, Tournilhac O. State-of-the-art for CAR T-cell therapy for chronic lymphocytic leukemia in (2019). J Immunother Cancer. (2019) 7:202. doi: 10.1186/s40425-019-0686-x

181. Flinn I, Marris M, Wierda WG, Coutre S, Pagel JM, Byrd JC, et al. ZUMA8: a phase 1/2 multicenter study evaluating KTE-X19 in patients (pts) with relapsed/refractory (R/R) chronic lymphocytic leukemia (CLL). J Clin Oncol. (2019) 37(Suppl. 15):TPS7566. doi: 10.1200/JCO.2019.37.15_suppl.TPS7566

182. Riches JC, Davies JK, McClanahan F, Fatah R, Iqbal S, Agrawal S, et al. $\mathrm{T}$ cells from CLL patients exhibit features of T-cell exhaustion but retain capacity for cytokine production. Blood. (2013) 121:161221. doi: 10.1182/blood-2012-09-457531

183. Hoffmann JM, Schubert ML, Wang L, Huckelhoven A, Sellner L, Stock S, et al. Differences in expansion potential of naive chimeric antigen receptor $\mathrm{T}$ cells from healthy donors and untreated chronic lymphocytic leukemia patients. Front Immunol. (2017) 8:1956. doi: 10.3389/fimmu.2017.01956

184. Gauthier J, Hirayama AV, Purushe J, Hay KA, Lymp J, Li D, et al. Feasibility and efficacy of CD19-targeted CAR-T cells with concurrent Ibrutinib for CLL after ibrutinib failure. Blood. (2020) 19. doi: 10.1182/blood.2019002936

185. Faitschuk E, Hombach AA, Frenzel LP, Wendtner CM, Abken H. Chimeric antigen receptor $\mathrm{T}$ cells targeting $\mathrm{Fc}$ mu receptor selectively eliminate CLL cells while sparing healthy B cells. Blood. (2016) 128:171122. doi: 10.1182/blood-2016-01-692046

186. Giordano Attianese GM, Marin V, Hoyos V, Savoldo B, Pizzitola I, Tettamanti S, et al. In vitro and in vivo model of a novel immunotherapy approach for chronic lymphocytic leukemia by anti-CD23 chimeric antigen receptor. Blood. (2011) 117:4736-45. doi: 10.1182/blood-2010-10-311845

187. Berdeja JG, Lin Y, Raje N, Munshi N, Siegel D, Liedtke M, et al. Durable clinical responses in heavily pretreated patients with relapsed/refractory multiple myeloma: updated results from a multicenter study of 
bb2121 anti-bcma CAR T cell therapy. Blood. (2017) 130(Suppl. 1):740. doi: 10.1182/blood.V130.Suppl_1.740.740

188. Brudno JN, Maric I, Hartman SD, Rose JJ, Wang M, Lam N, et al. T cells genetically modified to express an anti-B-cell maturation antigen chimeric antigen receptor cause remissions of poor-prognosis relapsed multiple myeloma. J Clin Oncol. (2018) 36:2267-80. doi: 10.1200/JCO.2018.77.8084

189. Cohen AD, Garfall AL, Stadtmauer EA, Melenhorst JJ, Lacey SF, Lancaster $\mathrm{E}$, et al. B cell maturation antigen-specific CAR T cells are clinically active in multiple myeloma. JClin Invest. (2019) 129:2210-21. doi: 10.1172/JCI126397

190. Raje N, Berdeja J, Lin Y, Siegel D, Jagannath S, Madduri D, et al. Anti-BCMA CAR T-cell therapy bb2121 in relapsed or refractory multiple myeloma. $N$ Engl J Med. (2019) 380:1726-37. doi: 10.1056/NEJMoal817226

191. Miguel JS, Weisel K, Moreau P, Lacy M, Song K, Delforge M, et al. Pomalidomide plus low-dose dexamethasone versus high-dose dexamethasone alone for patients with relapsed and refractory multiple myeloma (MM-003): a randomised, open-label, phase 3 trial. Lancet Oncol. (2013) 14:1055-66. doi: 10.1016/S1470-2045(13)70380-2

192. Lonial S, Weiss BM, Usmani SZ, Singhal S, Chari A, Bahlis NJ, et al. Daratumumab monotherapy in patients with treatment-refractory multiple myeloma (SIRIUS): an open-label, randomised, phase 2 trial. Lancet. (2016) 387:1551-60. doi: 10.1016/S0140-6736(15)01120-4

193. Zhao WH, Liu J, Wang BY, Chen YX, Cao XM, Yang Y, et al. A phase 1, open-label study of LCAR-B38M, a chimeric antigen receptor $\mathrm{T}$ cell therapy directed against $\mathrm{B}$ cell maturation antigen, in patients with relapsed or refractory multiple myeloma. J Hematol Oncol. (2018) 11:141. doi: 10.1186/s13045-018-0681-6

194. Hamieh M, Dobrin A, Cabriolu A, van der Stegen SJC, Giavridis T, MansillaSoto J, et al. CAR T cell trogocytosis and cooperative killing regulate tumour antigen escape. Nature. (2019) 568:112-6. doi: 10.1038/s41586-019-1054-1

195. Yan Z, Cao J, Cheng H, Qiao J, Zhang H, Wang Y, et al. A combination of humanised anti-CD19 and anti-BCMA CAR T cells in patients with relapsed or refractory multiple myeloma: a single-arm, phase 2 trial. Lancet Haematol. (2019) 6:e521-9. doi: 10.1016/S2352-3026(19)30115-2

196. Timmers M, Roex G, Wang Y, Campillo-Davo D, Van Tendeloo VFI, Chu $\mathrm{Y}$, et al. Chimeric antigen receptor-modified $\mathrm{t}$ cell therapy in multiple myeloma: beyond b cell maturation antigen. Front Immunol. (2019) 10:1613. doi: 10.3389/fimmu.2019.01613

197. Casucci M, Nicolis di Robilant B, Falcone L, Camisa B, Norelli M, Genovese $\mathrm{P}$, et al. CD44v6-targeted T cells mediate potent antitumor effects against acute myeloid leukemia and multiple myeloma. Blood. (2013) 122:346172. doi: 10.1182/blood-2013-04-493361

198. Peinert S, Prince HM, Guru PM, Kershaw MH, Smyth MJ, Trapani JA, et al. Gene-modified $\mathrm{T}$ cells as immunotherapy for multiple myeloma and acute myeloid leukemia expressing the Lewis Y antigen. Gene Ther. (2010) 17:678-86. doi: 10.1038/gt.2010.21

199. Nikiforow S, Werner L, Murad J, Jacobs M, Johnston L, Patches S, et al. Safety data from a first-in-human phase 1 trial of NKG2D chimeric antigen receptor-T cells in AML/MDS and multiple myeloma. Blood. (2016) 128:4052. doi: 10.1182/blood.V128.22.4052.4052

200. Venniyil Radhakrishnan S, Luetkens T, Yousef S, Bhardwaj N, Steinbach MN, Weidner J, et al. Chimeric antigen receptor (CAR) T cells specific for CD229: a potentially curative approach for multiple myeloma. Blood. (2017) 130(Suppl. 1):3142. doi: 10.1182/blood.V130.Suppl_1.3142.3142

201. Hosen N, Matsunaga Y, Hasegawa K, Matsuno H, Nakamura Y, Makita $\mathrm{M}$, et al. The activated conformation of integrin beta7 is a novel multiple myeloma-specific target for CAR T cell therapy. Nat Med. (2017) 23:143643. doi: $10.1038 / \mathrm{nm} .4431$

202. Wang CM, Wu ZQ, Wang Y, Guo YL, Dai HR, Wang XH, et al. Autologous $\mathrm{T}$ cells expressing CD30 chimeric antigen receptors for relapsed or refractory hodgkin lymphoma: an open-label phase i trial. Clin Cancer Res. (2017) 23:1156-66. doi: 10.1158/1078-0432.CCR-16-1365

203. Ramos CA, Ballard B, Zhang H, Dakhova O, Gee AP, Mei Z, et al. Clinical and immunological responses after CD30-specific chimeric antigen receptor-redirected lymphocytes. J Clin Invest. (2017) 127:346271. doi: $10.1172 /$ JCI94306

204. Ramos CA, Bilgi M, Gerken C, Dakhova O, Mei Z, Wu MF, et al. CD30-Chimeric Antigen Receptor (CAR) $\mathrm{T}$ cells for therapy of Hodgkin Lymphoma (HL). Biol Blood Marrow Transpl. (2019) 25:S63. doi: $10.1016 /$ j.bbmt.2018.12.145
205. Scherer LD, Brenner MK, Mamonkin M. Chimeric antigen receptors for T-cell malignancies. Front Oncol. (2019) 9:126. doi: 10.3389/fonc.2019.00126

206. Alcantara M, Tesio M, June CH, Houot R. CAR T-cells for T-cell malignancies: challenges in distinguishing between therapeutic, normal, and neoplastic T-cells. Leukemia. (2018) 32:2307-15. doi: 10.1038/s41375-018-0285-8

207. Sanchez-Martinez D, Baroni ML, Gutierrez-Aguera F, Roca-Ho H, BlanchLombarte O, Gonzalez-Garcia S, et al. Fratricide-resistant CD1a-specific CAR T cells for the treatment of cortical T-cell acute lymphoblastic leukemia. Blood. (2019) 133:2291-304. doi: 10.1182/blood-2018-10-882944

208. Huang J, Alexey S, Li J, Jones T, Grande G, Douthit L, et al. Correction: unique CDR3 epitope targeting by CAR-T cells is a viable approach for treating T-cell malignancies. Leukemia. (2019) 33:2341. doi: 10.1038/s41375-019-0484-y

209. Gomes-Silva D, Srinivasan M, Sharma S, Lee CM, Wagner DL, Davis $\mathrm{TH}$, et al. CD7-edited $\mathrm{T}$ cells expressing a CD7-specific CAR for the therapy of T-cell malignancies. Blood. (2017) 130:285-96. doi: 10.1182/blood-2017-01-761320

210. Cerrano M, Itzykson R. New Treatment Options for Acute Myeloid Leukemia in (2019). Curr Oncol Rep. (2019) 21:16. doi: 10.1007/s11912-019-0764-8

211. Cheever MA, Allison JP, Ferris AS, Finn OJ, Hastings BM, Hecht TT, et al. The prioritization of cancer antigens: a national cancer institute pilot project for the acceleration of translational research. Clin Cancer Res. (2009) 15:5323-37. doi: 10.1158/1078-0432.CCR-09-0737

212. Hofmann S, Schubert ML, Wang L, He B, Neuber B, Dreger P, et al. Chimeric Antigen Receptor (CAR) T cell therapy in Acute Myeloid Leukemia (AML). J Clin Med. (2019) 8:200. doi: 10.3390/jcm8020200

213. Cummins KD, Gill S. Will CAR $\mathrm{T}$ cell therapy have a role in AML? promises and pitfalls. Semin Hematol. (2019) 56:15563. doi: 10.1053/j.seminhematol.2018.08.008

214. Feng KC, Guo YL, Liu Y, Dai HR, Wang Y, Lv HY, et al. Cocktail treatment with EGFR-specific and CD133-specific chimeric antigen receptor-modified $\mathrm{T}$ cells in a patient with advanced cholangiocarcinoma. J Hematol Oncol. (2017) 10:4. doi: 10.1186/s13045-016-0378-7

215. Lamers CH, Sleijfer S, van Steenbergen S, van Elzakker P, van Krimpen B, Groot C, et al. Treatment of metastatic renal cell carcinoma with CAIX CARengineered $\mathrm{T}$ cells: clinical evaluation and management of on-target toxicity. Mol Ther. (2013) 21:904-12. doi: 10.1038/mt.2013.17

216. Morgan RA, Yang JC, Kitano M, Dudley ME, Laurencot CM, Rosenberg SA. Case report of a serious adverse event following the administration of $\mathrm{T}$ cells transduced with a chimeric antigen receptor recognizing ERBB2. Mol Ther. (2010) 18:843-51. doi: 10.1038/mt.2010.24

217. Thistlethwaite FC, Gilham DE, Guest RD, Rothwell DG, Pillai M, Burt DJ, et al. The clinical efficacy of first-generation carcinoembryonic antigen (CEACAM5)-specific CAR T cells is limited by poor persistence and transient pre-conditioning-dependent respiratory toxicity. Cancer Immunol Immunother CII. (2017) 66:1425-36. doi: 10.1007/s00262-017-2034-7

218. Perna F, Berman SH, Soni RK, Mansilla-Soto J, Eyquem J, Hamieh M, et al. Integrating proteomics and transcriptomics for systematic combinatorial chimeric antigen receptor therapy of AML. Cancer Cell. (2017) 32:50619. doi: 10.1016/j.ccell.2017.09.004

219. Akahori Y, Wang L, Yoneyama M, Seo N, Okumura S, Miyahara $\mathrm{Y}$, et al. Antitumor activity of CAR-T cells targeting the intracellular oncoprotein WT1 can be enhanced by vaccination. Blood. (2018) 132:113445. doi: 10.1182/blood-2017-08-802926

220. Cartellieri M, Feldmann A, Koristka S, Arndt C, Loff S, Ehninger A, et al. Switching CAR T cells on and off: a novel modular platform for retargeting of T cells to AML blasts. Blood Cancer J. (2016) 6:e458. doi: 10.1038/bcj.2016.61

221. Beatty GL, O'Hara MH, Lacey SF, Torigian DA, Nazimuddin F, Chen F, et al. Activity of mesothelin-specific chimeric antigen receptor $T$ cells against pancreatic carcinoma metastases in a phase 1 trial. Gastroenterology. (2018) 155:29-32. doi: 10.1053/j.gastro.2018.03.029

222. Cummins KD, Frey N, Nelson AM, Schmidt A, Luger S, Isaacs RE, et al. Treating Relapsed / Refractory (RR) AML with biodegradable anti-CD123 CAR modified T cells. Blood. (2017) 130(Suppl. 1):1359. doi: 10.1182/blood.V130.Suppl_1.1359.1359

223. Minagawa K, Jamil MO, Al-Obaidi M, Pereboeva L, Salzman D, Erba HP, et al. In Vitro pre-clinical validation of suicide gene modified anti-CD33 
redirected chimeric antigen receptor t-cells for acute myeloid leukemia. PLoS One. (2016) 11:e0166891. doi: 10.1371/journal.pone.0166891

224. Bielamowicz K, Fousek K, Byrd TT, Samaha H, Mukherjee M, Aware N, et al. Trivalent CAR T cells overcome interpatient antigenic variability in glioblastoma. Neuro Oncol. (2018) 20:506-18. doi: 10.1093/neuonc/nox182

225. Cummins KD, Gill S. Anti-CD123 chimeric antigen receptor T-cells (CART): an evolving treatment strategy for hematological malignancies, and a potential ace-in-the-hole against antigen-negative relapse. Leuk Lymphoma. (2018) 59:1539-53. doi: 10.1080/10428194.2017.1375107

226. Haubner S, Perna F, Kohnke T, Schmidt C, Berman S, Augsberger $\mathrm{C}$, et al. Coexpression profile of leukemic stem cell markers for combinatorial targeted therapy in AML. Leukemia. (2019) 33:64-74. doi: 10.1038/s41375-018-0180-3

227. Krawczyk E, Zolov SN, Huang K, Bonifant CL. T-cell activity against AML improved by dual-targeted $\mathrm{T}$ cells stimulated through T-cell and IL7 receptors. Cancer Immunol Res. (2019) 7:683-92. doi: 10.1158/2326-6066.CIR-18-0748

228. Wilkie S, van Schalkwyk MC, Hobbs S, Davies DM, van der Stegen SJ, Pereira $\mathrm{AC}$, et al. Dual targeting of ErbB2 and MUC1 in breast cancer using chimeric antigen receptors engineered to provide complementary signaling. J Clin Immunol. (2012) 32:1059-70. doi: 10.1007/s10875-012-9689-9

229. Zhang E, Yang P, Gu J, Wu H, Chi X, Liu C, et al. Recombination of a dualCAR-modified T lymphocyte to accurately eliminate pancreatic malignancy. J Hematol Oncol. (2018) 11:102. doi: 10.1186/s13045-018-0646-9

230. Martinez M, Moon EK. CAR T cells for solid tumors: new strategies for finding, infiltrating, and surviving in the tumor microenvironment. Front Immunol. (2019) 10:128. doi: 10.3389/fimmu.2019.00128

231. Katz SC, Point GR, Cunetta M, Thorn M, Guha P, Espat NJ, et al. Regional CAR-T cell infusions for peritoneal carcinomatosis are superior to systemic delivery. Cancer Gene Ther. (2016) 23:142-8. doi: 10.1038/cgt.2016.14

232. Liu H, Xu Y, Xiang J, Long L, Green S, Yang Z, et al. Targeting alphaFetoprotein (AFP)-MHC complex with CAR T-cell therapy for liver cancer. Clin Cancer Res. (2017) 23:478-88. doi: 10.1158/1078-0432.CCR16-1203

233. Caruana I, Savoldo B, Hoyos V, Weber G, Liu H, Kim ES, et al. Heparanase promotes tumor infiltration and antitumor activity of CAR-redirected T lymphocytes. Nat Med. (2015) 21:524-9. doi: 10.1038/nm.3833

234. Whilding LM, Vallath S, Maher J. The integrin alphavbeta6: a novel target for CAR T-cell immunotherapy? Biochem Soc Trans. (2016) 44:34955. doi: 10.1042/BST20150249

235. Heczey A, Louis CU, Savoldo B, Dakhova O, Durett A, Grilley B, et al. CAR T cells administered in combination with lymphodepletion and PD1 inhibition to patients with neuroblastoma. Mol Ther. (2017) 25:221424. doi: 10.1016/j.ymthe.2017.05.012

236. Yoon DH, Osborn MJ, Tolar J, Kim CJ. Incorporation of immune checkpoint blockade into chimeric antigen receptor T cells (CAR-Ts): combination or built-In CAR-T. Int J Mol Sci. (2018) 19:340. doi: 10.3390/ijms19020340

237. Li J, Li W, Huang K, Zhang Y, Kupfer G, Zhao Q. Chimeric antigen receptor $\mathrm{T}$ cell (CAR-T) immunotherapy for solid tumors: lessons learned and strategies for moving forward. J Hematol Oncol. (2018) 11:22. doi: 10.1186/s13045-018-0568-6

238. Ren J, Zhao Y. Advancing chimeric antigen receptor $\mathrm{T}$ cell therapy with CRISPR/Cas9. Protein Cell. (2017) 8:63443. doi: 10.1007/s13238-017-0410-x

239. Singh N, Shi J, June CH, Ruella M. Genome-editing technologies in adoptive T cell immunotherapy for cancer. Curr Hematol Malig Rep. (2017) 12:5229. doi: 10.1007/s11899-017-0417-7

240. Torikai H, Reik A, Liu PQ, Zhou Y, Zhang L, Maiti S, et al. A foundation for universal T-cell based immunotherapy: $\mathrm{T}$ cells engineered to express a CD19-specific chimeric-antigen-receptor and eliminate expression of endogenous TCR. Blood. (2012) 119:5697-705. doi: 10.1182/blood-2012-01405365

241. Perez EE, Wang J, Miller JC, Jouvenot Y, Kim KA, Liu O, et al. Establishment of HIV-1 resistance in CD4+ T cells by genome editing using zinc-finger nucleases. Nat Biotechnol. (2008) 26:808-16. doi: 10.1038/nbt1410

242. Miller JC, Tan S, Qiao G, Barlow KA, Wang J, Xia DF, et al. A TALE nuclease architecture for efficient genome editing. Nat Biotechnol. (2011) 29:143-8. doi: 10.1038/nbt.1755
243. Osborn MJ, Webber BR, Knipping F, Lonetree CL, Tennis N, DeFeo AP, et al. Evaluation of TCR gene editing achieved by TALENs, CRISPR/Cas9, and megaTAL nucleases. Mol Ther. (2016) 24:570-81. doi: 10.1038/mt.2015.197

244. Sather BD, Romano Ibarra GS, Sommer K, Curinga G, Hale M, Khan IF, et al. Efficient modification of CCR5 in primary human hematopoietic cells using a megaTAL nuclease and AAV donor template. Sci Transl Med. (2015) 7:307ra156. doi: 10.1126/scitranslmed.aac5530

245. Cong L, Ran FA, Cox D, Lin S, Barretto R, Habib N, et al. Multiplex genome engineering using CRISPR/Cas systems. Science. (2013) 339:81923. doi: 10.1126/science.1231143

246. Sommer C, Boldajipour B, Kuo TC, Bentley T, Sutton J, Chen A, et al. Preclinical evaluation of allogeneic CAR T cells targeting BCMA for the treatment of multiple myeloma. Mol Ther. (2019) 27:112638. doi: 10.1016/j.ymthe.2019.04.001

247. Torikai H, Reik A, Soldner F, Warren EH, Yuen C, Zhou Y, et al. Toward eliminating HLA class I expression to generate universal cells from allogeneic donors. Blood. (2013) 122:1341-9. doi: 10.1182/blood-2013-03-478255

248. Gornalusse GG, Hirata RK, Funk SE, Riolobos L, Lopes VS, Manske G, et al. HLA-E-expressing pluripotent stem cells escape allogeneic responses and lysis by NK cells. Nat Biotechnol. (2017) 35:765-72. doi: 10.1038/nbt.3860

249. Jandus C, Boligan KF, Chijioke O, Liu H, Dahlhaus M, Demoulins T, et al. Interactions between Siglec-7/9 receptors and ligands influence NK cell-dependent tumor immunosurveillance. J Clin Invest. (2014) 124:181020. doi: $10.1172 / \mathrm{JCI} 65899$

250. Ren J, Zhang X, Liu X, Fang C, Jiang S, June CH, et al. A versatile system for rapid multiplex genome-edited CAR T cell generation. Oncotarget. (2017) 8:17002-11. doi: $10.18632 /$ oncotarget. 15218

251. Themeli M, Kloss CC, Ciriello G, Fedorov VD, Perna F, Gonen M, et al. Generation of tumor-targeted human T lymphocytes from induced pluripotent stem cells for cancer therapy. Nat Biotechnol. (2013) 31:92833. doi: $10.1038 /$ nbt.2678

252. Clarke R, Van Der Stegen S, Chang C-W, Husain M, Lai Y-S, Peralta E, et al. Pluripotent cell-derived off-the-shelf TCR-less CAR-targeted cytotoxic T cell therapeutic for the allogeneic treatment of B cell malignancies. Blood. (2018) 132(Suppl. 1):4546. doi: 10.1182/blood-2018-99-116843

253. Rey J, Veuillen C, Vey N, Bouabdallah R, Olive D. Natural killer and gammadelta $\mathrm{T}$ cells in haematological malignancies: enhancing the immune effectors. Trends Mol Med. (2009) 15:275-84. doi: 10.1016/j.molmed.2009.04.005

254. Quintarelli C, Sivori S, Caruso S, Carlomagno S, Falco M, Boffa I, et al. Efficacy of third-party chimeric antigen receptor modified peripheral blood natural killer cells for adoptive cell therapy of Bcell precursor acute lymphoblastic leukemia. Leukemia. (2019) 34:110215. doi: $10.1038 / \mathrm{s} 41375-019-0613-7$

255. Shah N, Martin-Antonio B, Yang H, Ku S, Lee DA, Cooper LJ, et al. Antigen presenting cell-mediated expansion of human umbilical cord blood yields log-scale expansion of natural killer cells with anti-myeloma activity. PloS One. (2013) 8:e76781. doi: 10.1371/journal.pone.0076781

256. Liu E, Tong Y, Dotti G, Shaim H, Savoldo B, Mukherjee M, et al. Cord blood NK cells engineered to express IL-15 and a CD19-targeted CAR show long-term persistence and potent antitumor activity. Leukemia. (2018) 32:520-31. doi: 10.1038/leu.2017.226

257. Liu E, Marin D, Banerjee P, Macapinlac HA, Thompson P, Basar R, et al. Use of CAR-transduced natural killer cells in CD19-positive lymphoid tumors. $N$ Engl J Med. (2020) 382:545-53. doi: 10.1056/NEJMoa1910607

258. Gong JH, Maki G, Klingemann HG. Characterization of a human cell line (NK-92) with phenotypical and functional characteristics of activated natural killer cells. Leukemia. (1994) 8:652-8.

259. Reid GS, Bharya S, Klingemann HG, Schultz KR. Differential killing of pre-B acute lymphoblastic leukaemia cells by activated NK cells and the NK-92 ci cell line. Clin Exp Immunol. (2002) 129:26571. doi: 10.1046/j.1365-2249.2002.01919.x

260. Boissel L, Betancur M, Wels WS, Tuncer H, Klingemann H. Transfection with mRNA for CD19 specific chimeric antigen receptor restores NK cell mediated killing of CLL cells. Leukemia Res. (2009) 33:12559. doi: 10.1016/j.leukres.2008.11.024

261. Boissel L, Betancur-Boissel M, Lu W, Krause DS, Van Etten RA, Wels WS, et al. Retargeting NK-92 cells by means of CD19- and CD20-specific chimeric 
antigen receptors compares favorably with antibody-dependent cellular cytotoxicity. Oncoimmunology. (2013) 2:e26527. doi: 10.4161/onci.26527

262. Romanski A, Uherek C, Bug G, Seifried E, Klingemann H, Wels WS, et al. CD19-CAR engineered NK-92 cells are sufficient to overcome NK cell resistance in B-cell malignancies. J Cell Mol Med. (2016) 20:128794. doi: $10.1111 / \mathrm{jcmm} .12810$

263. Tang X, Yang L, Li Z, Nalin AP, Dai H, Xu T, et al. First-in-man clinical trial of CAR NK-92 cells: safety test of CD33-CAR NK-92 cells in patients with relapsed and refractory acute myeloid leukemia. Am J Cancer Res. (2018) 8:1083-9.

264. WEB F. IEC, 2018: FACT WEB 2018. Available online at: http://www.factweb. org/forms/store/ProductFormPublic/first-edition-v1-1-fact-standards-forimmune-effector-cells-free-download (accessed June 6, 2018).

265. WEB F. HCT, 2018: FACT WEB 2018. Available online at: http://www. factweb.org/forms/store/ProductFormPublic/seventh-edition-fact-jacieinternational-standards-for-hematopoietic-cellular-therapy-productcollection-processing-and-administration-free-download (accessed June $25,2018)$.

266. Levine BL, Miskin J, Wonnacott K, Keir C. Global manufacturing of CAR T cell therapy. Mol Ther Methods Clin Dev. (2017) 4:92101. doi: 10.1016/j.omtm.2016.12.006

267. McGuirk J, Waller EK, Qayed M, Abhyankar S, Ericson S, Holman P, et al. Building blocks for institutional preparation of CTL019 delivery. Cytotherapy. (2017) 19:1015-24. doi: 10.1016/j.jcyt.2017.06.001

268. Perica K, Curran KJ, Brentjens RJ, Giralt SA. Building a CAR garage: preparing for the delivery of commercial CAR $\mathrm{T}$ cell products at memorial sloan kettering cancer center. Biol Blood Marrow Transplant. (2018) 24:1135-41. doi: 10.1016/j.bbmt.2018.02.018

269. Wang X, Rivière I. Clinical manufacturing of CAR $T$ cells: foundation of a promising therapy. Mol Ther Oncolytics. (2016) 3:16015. doi: $10.1038 / \mathrm{mto} .2016 .15$

270. Anderson K, Latchford T. Associated toxicities: assessment and management related to CAR T-cell therapy. Clin J Oncol Nurs. (2019) 23:139. doi: 10.1188/19.CJON.S1.13-19

271. Jacobson CA, Farooq U, Ghobadi A. Axicabtagene ciloleucel, an anti-CD19 chimeric antigen receptor T-cell therapy for relapsed or refractory large B-cell lymphoma: practical implications for the community oncologist. Oncologist. (2020) 25:e138-46. doi: 10.1634/theoncologist.2019-0395

272. WEB E. EMA, 2018: EMA WEB 2018. Available online at: http://www.ema. europa.eu/docs/en_GB/document_library/Report/2018/05/WC500249247. pdf (accessed June 25, 2018).

273. WEB E. APPENDIX, 2018: EMA WEB 2018. Available online at: http:// www.ema.europa.eu/docs/en_GB/document_library/Report/2018/05/ WC500249248.pdf (accessed June 25, 2018).

274. Dourthe ME, Cabannes-Hamy A, Yakouben K, Fabian F, Chaillou D, Chevillon F, et al. Safety and efficacy of tisagenlecleucel (CTL019) in b acute lymphoblastic leukemia in children and young adults: robert debré and saint louis hospitals experience: PS943. HemaSphere. (2019) 3:425. doi: 10.1097/01.HS9.0000562044.39405.b4

275. Jacobson CA, Hunter B, Armand P, Kamihara Y, Ritz J, Rodig SJ, et al. Axicabtagene ciloleucel in the real world: outcomes and predictors of response, resistance and toxicity. Blood. (2018) 132(Suppl. 1):92. doi: 10.1182/blood-2018-99-117199

276. Nastoupil LJ, Jain MD, Spiegel JY, Ghobadi A, Lin Y, Dahiya S, et al. Axicabtagene ciloleucel (Axi-cel) CD19 Chimeric Antigen Receptor (CAR) T-cell therapy for Relapsed/Refractory large Bcell lymphoma: real world experience. Blood. (2018) 132(Suppl. 1):91. doi: 10.1182/blood-2018-99-114152

277. Frigault MJ, Dietrich J, Martinez-Lage M, Leick M, Choi BD, DeFilipp Z, et al. Tisagenlecleucel CAR-T cell therapy in secondary CNS lymphoma. Blood. (2019) 134:860-6. doi: 10.1182/blood.2019001694

278. Kansagra AJ, Frey NV, Bar M, Laetsch TW, Carpenter PA, Savani BN, et al. Clinical utilization of Chimeric Antigen Receptor T-cells (CAR-T) in B-cell acute lymphoblastic leukemia (ALL)-an expert opinion from the European Society for Blood and Marrow Transplantation (EBMT) and the American Society for Blood and Marrow Transplantation (ASBMT). Bone Marrow Transplantation. (2019) 54:1868-80. doi: 10.1038/s41409-019-0451-2

279. Pillai V, Muralidharan K, Meng W, Bagashev A, Oldridge DA, Rosenthal J, et al. CAR T-cell therapy is effective for CD19-dim B-lymphoblastic leukemia but is impacted by prior blinatumomab therapy. Blood Adv. (2019) 3:3539-49. doi: 10.1182/bloodadvances.2019000692

280. Abramson JS, Palomba ML, Gordon LI, Lunning MA, Arnason JE, Wang $M$, et al. High durable CR rates in Relapsed/Refractory (R/R) aggressive B-NHL treated with the CD19-directed CAR $\mathrm{T}$ cell product JCAR017 (TRANSCEND NHL 001): defined composition allows for dose-finding and definition of pivotal cohort. Blood. (2017) 130(Suppl. 1):581. doi: 10.1002/hon.2437_127

281. Hunter BD, Chen YB, Jacobson CA. Allogeneic stem cell transplantation and Chimeric Antigen Receptor (CAR) T-cell therapy for the treatment of non-hodgkin lymphoma. Hematol Oncol Clin North Am. (2019) 33:687705. doi: $10.1016 /$ j.hoc.2019.03.005

282. Sauter CS, Senechal B, Riviere I, Ni A, Bernal Y, Wang X, et al. CD19 CAR $\mathrm{T}$ cells following autologous transplantation in poor-risk relapsed and refractory B-cell non-Hodgkin lymphoma. Blood. (2019) 134:62635. doi: 10.1182/blood.2018883421

283. Sarkar RR, Gloude NJ, Schiff D, Murphy JD. Cost-effectiveness of chimeric antigen receptor T-cell therapy in pediatric relapsed/refractory B-cell acute lymphoblastic leukemia. J Natl Cancer Inst. (2018) 111:71926. doi: 10.1093/jnci/djy193

284. Whittington MD, McQueen RB, Ollendorf DA, Kumar VM, Chapman RH, Tice JA, et al. Long-term survival and cost-effectiveness associated with axicabtagene ciloleucel vs chemotherapy for treatment of B-cell lymphoma. JAMA Netw Open. (2019) 2:e190035. doi: 10.1001/jamanetworkopen.2019. 0035

285. Roth JA, Sullivan SD, Lin VW, Bansal A, Purdum AG, Navale L, et al. Cost-effectiveness of axicabtagene ciloleucel for adult patients with relapsed or refractory large B-cell lymphoma in the United States. J Med Econ. (2018) 21:1238-45. doi: 10.1080/13696998.2018. 1529674

286. Lin JK, Muffly LS, Spinner MA, Barnes JI, Owens DK, Goldhaber-Fiebert JD. Cost effectiveness of chimeric antigen receptor T-cell therapy in multiply relapsed or refractory adult large b-cell lymphoma. J Clin Oncol. (2019) 37:2105-19. doi: 10.1200/JCO.18.02079

287. Lin JK, Lerman BJ, Barnes JI, Boursiquot BC, Tan YJ, Robinson AQL, et al. Cost effectiveness of chimeric antigen receptor T-cell therapy in relapsed or refractory pediatric B-cell acute lymphoblastic leukemia. J Clin Oncol. (2018) 36:3192-202. doi: 10.1200/JCO.2018.79.0642

288. Zhu F, Shah NN, Schneider D, Xu H, Chaney K, Luib L, et al. Pointof-care manufacturing of CD20.19 bi-specific Chimeric Antigen Receptor $\mathrm{T}$ (CAR-T) cells in a standard academic cell processing facility for a phase i clinical trial in relapsed, refractory NHL. Blood. (2018) 132(Suppl. 1):4553. doi: 10.1182/blood-2018-99-116566

Conflict of Interest: MR has received research funding from Novartis; is the inventor in patents involving the use of CART immunotherapy for cancer; and is a consultant/advisor to Nanostring and Abclon. M-AP reports honoraria from Abbvie, Bellicum, Celgene, Bristol-Myers Squibb, Incyte, Merck, Novartis, Nektar Therapeutics, Omeros, and Takeda. He serves on DSMBs for Cidara Therapeutics, Servier and Medigene, and the scientific advisory boards of MolMed and NexImmune. He has received research support for clinical trials from Incyte, Kite/Gilead and Miltenyi Biotec. He serves in a volunteer capacity as a member of the Board of Directors of American Society for Transplantation and Cellular Therapy (ASTCT) and Be The Match (National Marrow Donor Program, NMDP), as well as on the CIBMTR Cellular Immunotherapy Data Resource (CIDR) Committee. GP is employed by Celgene Corporation.

The remaining authors declare that the research was conducted in the absence of any commercial or financial relationships that could be construed as a potential conflict of interest.

Copyright $\odot 2020$ Cerrano, Ruella, Perales, Vitale, Faraci, Giaccone, Coscia, Maloy, Sanchez-Escamilla, Elsabah, Fadul, Maffini, Pittari and Bruno. This is an openaccess article distributed under the terms of the Creative Commons Attribution License (CC BY). The use, distribution or reproduction in other forums is permitted, provided the original author(s) and the copyright owner(s) are credited and that the original publication in this journal is cited, in accordance with accepted academic practice. No use, distribution or reproduction is permitted which does not comply with these terms. 